\title{
Stress responses at the endometrial-placental interface regulate labyrinthine placental differentiation from trophoblast stem cells
}

\author{
D A Rappolee ${ }^{1,2,3,4,5,6,7}$, S Zhou ${ }^{1,4}$, E E Puscheck ${ }^{1,2,3}$ and Y Xie Pi,3 $^{1,3}$ \\ ${ }^{1}$ CS Mott Center for Human Growth and Development, ${ }^{2}$ Department of Obstetrics and Gynecology, ${ }^{3}$ Division of \\ Reproductive Endocrinology and Infertility, ${ }^{4}$ Program for Reproductive Sciences, Department of Physiology, \\ ${ }^{5}$ Institute for Environmental Health and Safety and ${ }^{6}$ Karmanos Cancer Institute, Wayne State University School of \\ Medicine, 275 East Hancock, Detroit, Michigan 48201, USA and ${ }^{7}$ Department of Biology, University of Windsor, \\ Windsor, Ontario, Canada N9B 3P4
}

Correspondence should be addressed to D A Rappolee at C S Mott Center for Human Growth and Development, Wayne State University School of Medicine; Email: drappole@med.wayne.edu

\begin{abstract}
Development can happen in one of two ways. Cells performing a necessary function can differentiate from stem cells before the need for it arises and stress does not develop. Or need arises before function, stress develops and stress signals are part of the normal stimuli that regulate developmental mechanisms. These mechanisms adjust stem cell differentiation to produce function in a timely and proportional manner. In this review, we will interpret data from studies of null lethal mutants for placental stress genes that suggest the latter possibility. Acknowledged stress pathways participate in stress-induced and -regulated differentiation in two ways. These pathways manage the homeostatic response to maintain stem cells during the stress. Stress pathways also direct stem cell differentiation to increase the first essential lineage and suppress later lineages when stem cell accumulation is diminished. This stress-induced differentiation maintains the conceptus during stress. Pathogenic outcomes arise because population sizes of normal stem cells are first depleted by decreased accumulation. The fraction of stem cells is further decreased by differentiation that is induced to compensate for smaller stem cell populations. Analysis of placental lethal null mutant genes known to mediate stress responses suggests that the labyrinthine placenta develops during, and is regulated by, hypoxic stress.
\end{abstract}

Reproduction (2013) 145 R139-R155

\section{Introduction and summary of goals of the review}

One goal of this review is to define the trophoblast and embryonic stem cell (TSC and ESC, respectively) lineages in the implanting embryo as the receiving center for normal and pathogenic stress signals for placental development. These signals come from the conceptus and the endometrium. The focus will be on how stress activates adaptive mechanisms that change from low to high exposures ('exposure' encompasses duration and magnitude) and pathogenic mechanisms with adverse effects at higher exposures. Adverse effects are mediated by compensatory and prioritized stem cell differentiation (Fig. 1), two phenomena we have discussed elsewhere (Rappolee et al. 2010, 2012, Xie et al. 2011). These stress response mechanisms are important shortly after implantation in mice during a period equivalent to the early part of the first-trimester in humans.

Another goal is to show that developmental plasticity builds on a foundation of normal mechanisms of development that are overlaid by a rheostat-type control regulated by stress. The normal mechanisms can be modulated by stress developing during normal development, but elevated stress can lead to adaptation or pathogenesis dependent on the stress exposure. This rheostat regulates the timing and magnitude of the proportional production of differentiated cell lineages. The rheostat regulates stem cells in a sequence of events during normal development and development regulated by elevated stress.

\section{What is stress?}

We have defined this previously (Rappolee 2007, Xie et al. 2011). In developmental terms, stress exposures of sufficient duration and magnitude cause diminished stem cell population growth. This affects the program that balances stem cell potency and differentiation.

We use the word stress in general terms, not to uniquely describe oxidative stress, endoplasmic reticulum (ER) stress, heat stress, 'metabolic stress' of malnutrition, genotoxic stress, or maternal stress hormone responses (Houghton et al. 1996, Kwong et al. 2000, Baumann et al. 2007, Burton et al. 2009, 


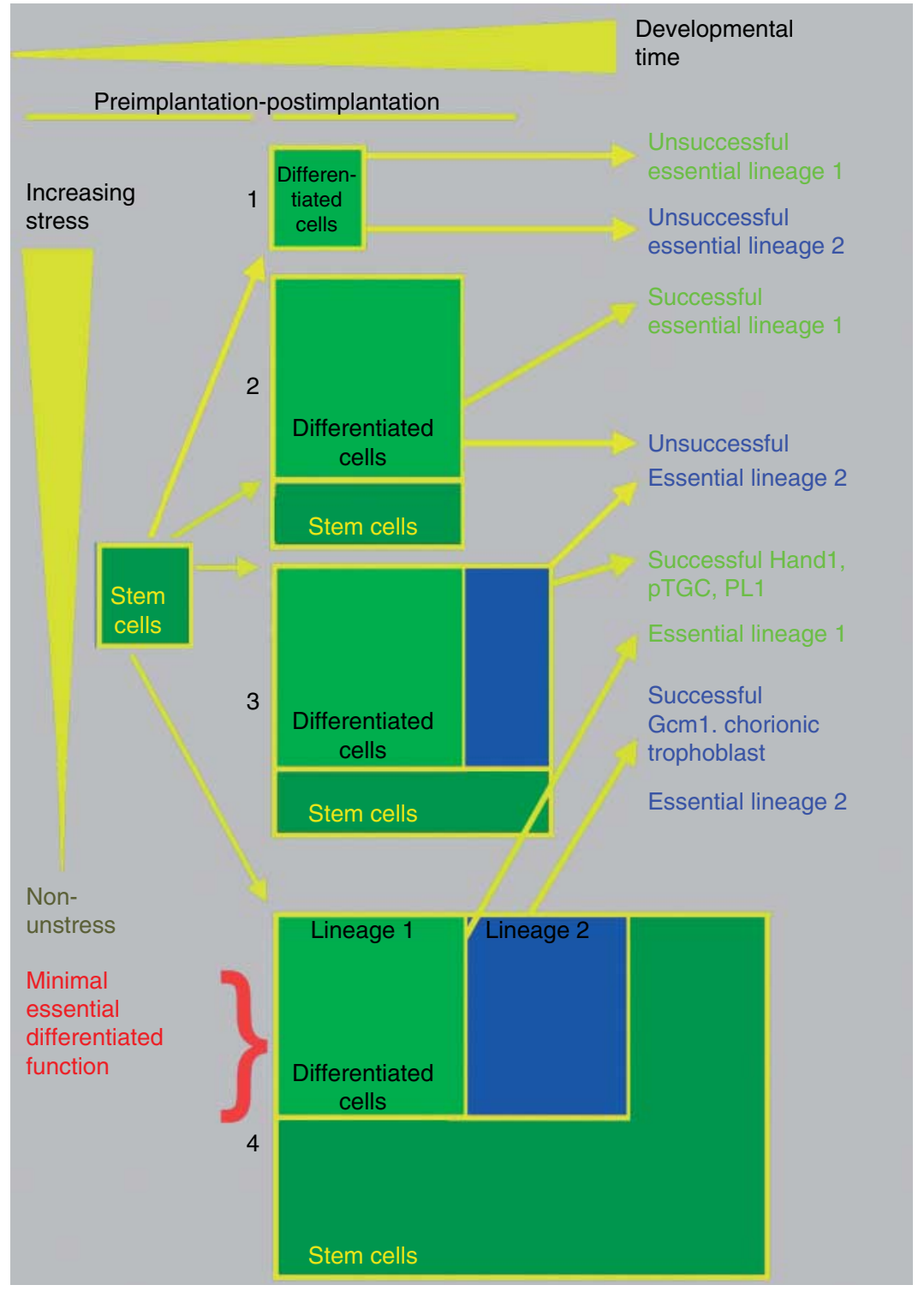

Figure 1 Diagram showing stress-induced compensatory and prioritized differentiation of TSC. Compensatory differentiation: as stress decreases the growth of the stem cell population (examples 2, 3 and 4), a higher fraction of differentiated cells compensates for fewer cells. For compensatory differentiation, note that 'minimal essential differentiated function' is denoted by a light green box for lineage 1 that is the same size as in examples 2, 3 and 4 . However, the size of the total box is smaller from examples $2<3<4$ resulting in greater differentiated product/cell in $2>$ $3>4$. Prioritized differentiation: as stress decreases the growth of the stem cell population (examples 3 and 4), early essential lineages are increased and later essential lineages are suppressed. Example 1, no stem cell growth from pre- to postimplantation results in spontaneous miscarriage before chemical pregnancy. This zero growth level of stress also converts all stem cells into the first lineage. Example 2, stem cell population growth only to minimal essential number of cells sufficient only for first essential lineage results in chemical pregnancy and spontaneous miscarriage. Example 3, sufficient stem cell population growth occurs for chemical pregnancy and partial essential lineage 2 then pregnancy loss. Example 4, normal unstressed stem cell population growth accommodates first and second essential lineages with stem cells in reserve. Reversible 'pseudo-differentiation' may rescue a range of decreased stem cell population sizes between examples 2, 3 and 4 and rescue pregnancy loss. Between examples 2 and 4, a range of pathophysiological stem cell differentiation strategies, some epigenetic, may result in long-term placental, fetal, and postnatal dysfunctions including preeclampsia, intrauterine growth restriction (IUGR) and developmental origins of health and disease (DOHAD) effects.
Scifres \& Nelson 2009, Mu et al. 2011, Xie et al. 2011). But all these are important and mediate shared stress outcomes such as diminished stem cell accumulation rates.

The early conceptus and its stem cells are highly anabolic. All cells in the implanting embryo are stem cells, except mural trophectoderm, and all divide. Early functions require high energy; one example is the pumping of the mural trophectodermal epithelium that makes the cyst in the blastocyst before implantation (Brison \& Leese 1991, 1994). Before implantation in mouse, energy is required for huge waves of new transcription at zygotic genome activation at the twocell stage and around the time of compaction at the eight cell stage (Hamatani et al. 2004, Wang et al. 2004). At these two stages, nearly 9000 types of mRNA transcripts are produced. Immediately after implantation, the production of endocrine, antiluteolytic hormones by the first differentiated placental cells and the epithelial nutrient acquisition of the first extraembryonic endoderm are necessary for survival and require high levels of energy (Rappolee 1999). Stressors that trigger reactive oxidative stress (ROS) or ER stress deplete energy that normally goes to stem cell population expansion and early differentiation events.

We focus on the common outcomes of stress responses. These are decreased anabolism, decreased proliferation, and increased fractions of stem cells that must differentiate to sustain essential functions after implantation. Stressors that decrease stem cell accumulation include malnutrition, maternal stress hormones, inflammatory cytokines, shear stress, improper culture media, improper $\mathrm{O}_{2}$ levels, environmental toxicants, and many others (Xie et al. 2011). Malnutrition in vivo or serum deprivation in vitro exacerbates other stresses by 
decreasing the carbon supply needed to support the stress response and maintain stress enzymes at a low level (Xie et al. 2011). Maternal leptin provides an endocrine signal proportional to, and produced by, adipocytes which signal that energy reserves are sufficient for reproduction (Krasnow \& Steiner 2006). But mouse oviductal and uterine epithelium provides paracrine confirmation of this leptin signal and can increase stem cell growth rates in the preimplantation embryo (Kawamura et al. 2003). In contrast, maternal adrenaline and cortisol can decrease blastocyst and stem cell growth in vitro and in vivo (Xie et al. 2011). These stresses lead to decreased stem cell accumulation and, by the mechanisms of compensatory and prioritized differentiation, stress-induced differentiation.

\section{Are there stress enzymes?}

This has been discussed previously (Xie et al. 2011). We will discuss several criteria that enable us to define as stress enzymes a small subset of approximately 500 protein kinases in the kinome (Caenepeel et al. 2004). We will use as an example two subfamilies of the MAPK superfamily; these are stress-activated protein kinases (SAPK) and p38MAPKs. Mammalian stress enzymes such as MAPK8/9/10 (SAPK/JNK1/2/3) and MAPK11-14 (p38MAPKs) are activated highly by many stresses (hyperosmolar stress, cytokines, toxicants, DNA damage, etc.) (Xie et al. 2011) but that mitogenic signaling MAPK1/3 (aka ERK) is not highly induced by these stresses. Conversely, mitogenic signals highly upregulate MAPK1/3 but not MAPK8/9 or MAPK11-14.

Stress enzymes and their immediate substrates are part of a 'health insurance policy' synthesized before stress, so it is not surprising that they mediate normal functions before stress levels increase. This does not diminish the significance of their role in mediating survival and other responses when stress levels increase.

Cultured cells under certain stressful conditions may require MAPK8/9 to permissively respond to stress so that cell division can occur. But overexpression of MAPK8/9 or their upstream activators MEK kinase (MEKK)4/7 has not been shown to instructively activate cell division. In contrast, MEKK1/2 overexpression and downstream MAPK1/3 activation can lead to transformation of cells in focus-forming assays (Cowley et al. 1994). MAPK8/9 function is complex and dependent on stress levels in early embryogenesis. During the stress of culture, MAPK $8 / 9$ is needed to sustain embryos in the most stressful media but slows development in the least stressful media (Wang et al. 2005, Xie et al. 2006). Thus, other mitogenic MAPKs are instructive and sufficient but stress enzymes MAPK8/9 may only be permissively involved with mitogenesis under special conditions. MAPK8/9 can be adaptive at lower stress exposures but can be pathogenic at higher, adverse exposures.

\section{Can stress serve as a normal cue for placental development?}

Emerging evidence suggests that the conceptus builds differentiation programs over time. These programs are partially guided during synthesis and triggered into activity by stress. Mouse null lethal mutants show how essential parenchymal function builds in the extraembryonic endoderm soon after implantation at E4.5-6.5 (Rappolee 1999), in heart, red blood cells, and a closed vascular system at E8.5, and in placental chorioallantoic fusion, villous vasculature and epithelium, and endometrial invasion by E11.5 (Copp 1995).

In this section, we analyze null mutants in known stress pathways that have a lethal phenotype due to placental dysfunction. The mutants were found using EndNote search engine set for 'all fields' or 'abstract' to screen the PubMed Database using key words 'placenta', 'knockout', 'lethal', and/or 'stress'.

It might be expected that the six placental lethals found by this search might be distributed throughout many placental cell types and throughout the major necessary period of placental function at E11.5 identified by null lethals in the seminal review by Copp (1995). Since this review by Copp, others have cataloged and analyzed nearly 100 placental null lethals (Rossant \& Cross 2001, Watson \& Cross 2005). Although our literature screen produced only six placental stress gene null lethals, five of these were shown to function at the surface of the mouse labyrinthine placenta. Furthermore, these lethalities developed over a 2-day period in a normal (unstressed) vivarium, E8.5-10.5, during the initiation of villous function (Table 1). We will interpret this as support for a model where need develops before function during development of the mouse labyrinthine placenta and that this results in stress. This stress requires response mechanisms that regulate intracellular stem cell adaptation and extracellular mechanisms that coordinate development of labyrinthine function.

\section{Introduction to Table 1}

$\mathrm{O}_{2}$ diffusion limitations trigger responses first observed at E8.5 when the mouse embryo reaches a size when functioning heart, closed vascular system, and red blood cells are required (Copp 1995). Extraembryonic endoderm and then placenta are required to provide nutrients derived from uterine glands and maternal blood. Chorioallantoic fusion occurs at E8.5 when mesenchyme digitates from the allantois into the chorion to form the labyrinthine cores. As the labyrinthine epithelium, consisting of sinusoidal trophoblast giant cells (sTGC) and syncytiotrophoblasts, differentiates, it develops the capability to sense low $\mathrm{O}_{2}$ as a stress. This induces vascular endothelial growth factor (VEGF) that induces villous endothelial cells via VEGF receptor (VEGFR)2 and tubularization through VEGFR1 (Hanahan 1997). 
Table 1 Stress enzyme and other stress mediators are important in placental development, as illustrated by null mutant lethal phenotypes ${ }^{\mathrm{a}}$.

\begin{tabular}{|c|c|c|c|}
\hline \multirow[b]{2}{*}{ Stress gene } & \multicolumn{2}{|c|}{ Earliest noted deviation $^{\mathrm{b}}$} & \multirow[b]{2}{*}{ Reference } \\
\hline & Onset, site of placental expression & Onset $^{\mathrm{b}}$, cause of lethality & \\
\hline \multirow[t]{2}{*}{ HuR (stress granule) } & $\begin{array}{l}\text { Unique cytoplasmic in labyrinthine } \\
\text { epithelium }\end{array}$ & E10.5 & Katsanou et al. (2009) \\
\hline & $\begin{array}{l}\text { Required in epithelium, deviated } \\
\text { at E8.5 }-9\end{array}$ & $\begin{array}{l}\text { Failure to initiate labyrinthine invasion } \\
\text { and branching }\end{array}$ & \\
\hline \multirow[t]{2}{*}{ p38MAPK $\alpha$ (stress enzyme) } & $\begin{array}{l}\text { Significant and required in labyrinthine } \\
\text { epithelium, deviated at E10.5 }\end{array}$ & E10.5 & Mudgett et al. (2000) \\
\hline & & $\begin{array}{l}\text { Failure of labyrinthine vascularization } \\
\text { after invasion }\end{array}$ & \\
\hline \multirow[t]{2}{*}{ HIF1 $\beta / A R N T$ (hypoxic stress) } & $\begin{array}{l}\text { Significant and required in labyrinthine } \\
\text { epithelium, deviated at E8.5 }\end{array}$ & E10.5 & Adelman et al. (2000a) \\
\hline & & $\begin{array}{l}\text { Failure of labyrinthine vascularization } \\
\text { after invasion }\end{array}$ & \\
\hline \multirow[t]{2}{*}{ HSP90 $\beta$ (heat stress) } & $\begin{array}{l}\text { Ubiquitous required in } \\
\text { mesenchyme, deviated at E10 }\end{array}$ & E10.5 & Voss et al. (2000) \\
\hline & & $\begin{array}{l}\text { Failure of labyrinthine vascularization, } \\
\text { yolk sac vascular failure E9.5-10.5 }\end{array}$ & \\
\hline \multirow[t]{2}{*}{ IRE1 (ER stress) } & $\begin{array}{l}\text { In labyrinthine epithelium and core, } \\
\text { ubiquitous E13.5 (only test time) }\end{array}$ & E13.5 & Iwawaki et al. (2009) \\
\hline & & $\begin{array}{l}\text { Failure of labyrinthine vascularization } \\
\text { after invasion }\end{array}$ & \\
\hline Mfn2 (highest energy) & Ubiquitous smaller embryos at E8.5 & $\begin{array}{l}\text { E11.5 } \\
\text { Failure to make TGC layer }\end{array}$ & Chen et al. (2003) \\
\hline
\end{tabular}

It is also possible that occult lineage imbalance occurs earlier but is not revealed by deficits in parenchymal function until a later essential requirement occurs.

a Note that these knockouts were analyzed in mice housed in a normal vivarium and should report endogenous stress-induced cues for normal development. Other knockouts with placental lethality due to stress responses not discussed in detail include JunB (Schorpp-Kistner et al. 1999), Oct1 (Sebastiano et al. 2010), PPARY (Barak et al. 1999), MEK1 (Giroux et al. 1999), Zfp36L1 tristetraprolin (TTP) family of tandem CCCH finger

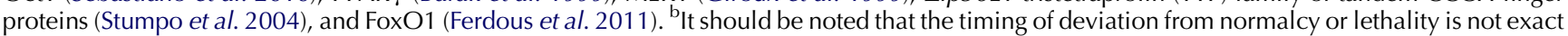
and dissimilar timings may represent differences in assays rather than biological reality. Timing of the beginning of morphological changes were observed as early as E8.5, before E9.5 when fetal $\mathrm{O}_{2}$ increases, indicating the start of functioning labyrinth (Fischer \& Bavister 1993). ${ }^{\mathrm{C}}$ The earliest vascularization lethality possible is indicated by null lethality of Flk1/VEGFR2 (endothelial cell induction mediator) and Flt1/VEGR1 (vascular tubule mediator), which occur at E8.5 (Hanahan 1997).

A series of null mutant genes are in stress pathways that feed into VEGF induction in the labyrinthine epithelium. We hypothesize that the VEGF pathway may be activated without stress, but it also has the capacity to be adjusted by hypoxic stress during development of the labyrinthine placenta.

Table 1 shows a number of mouse null mutants for stress enzymes and stress response genes that are needed for survival of the conceptus when gestational females are housed in a normal vivarium. These are multifunction genes, so it is not clear which functions in deficit lead to death. But these genes are in acknowledged stress pathways and similar stress response functions of the genes argue for their activation by an endogenous stress (Fig. 2). The stress is hypoxia and it induces autonomous cell survival and non-cell-autonomous differentiated neovascular and angiogenic induction by VEGF. We hypothesize that without the functions of these genes, VEGF induction is insufficient and/or the survival response of cells is insufficient.

Inositol-requiring enzyme 1 (IRE1) is the ER stress sensor (Table 1, Fig. 2) that activates protein kinase RNA (PKR), PKR-like ER kinase 1 (PERK1), and general control non-derepressible 2 (GCN2) that are able to phosphorylate eukaryotic translation initiation factor 2A (elF2a) (Back et al. 2005, Oikawa \& Kimata 2011). This leads to cessation of protein synthesis and is a canonical stress response to resist difficulties and stress and reestablish normal levels of ATP by slowing anabolism and increasing catabolism. elF2a phosphorylation leads to transfer of $m R N A$, translating in ribosomes into storage in human antigen $\mathrm{R}$ (HuR)-positive stress granules, not into P-bodies for destruction (Anderson \& Kedersha 2008). In humans, PERK1 is elevated in preeclamptic placenta, suggesting that these are under stress high enough to activate the unfolded protein response (Burton et al. 2010). In humans, this stress may be due to insufficient response to the oxidative stress of hypoxia-reoxygenation at the start of the second trimester. Second-trimester arterial hypoxia arises from insufficient trophoblast invasion in the first trimester. However, in cultured mouse trophoblast stem cell (TSC) models, implantation site hypoxia at $0.5 \%$ $\mathrm{O}_{2}$ or lower initiates the greatest induction of differentiation factor and greatest loss of potency factors (Zhou et al. 2011). This would impair initiation of normal mouse labyrinth differentiation that would emulate decreased human villous function in the first trimester.

The mouse null mutant shows that IRE1 is activated and functions through VEGFA to vascularize the labyrinthine placental core to create function that becomes essential by E12.5 (Iwawaki et al. 2009). However, this phenotype develops in a normal vivarium 


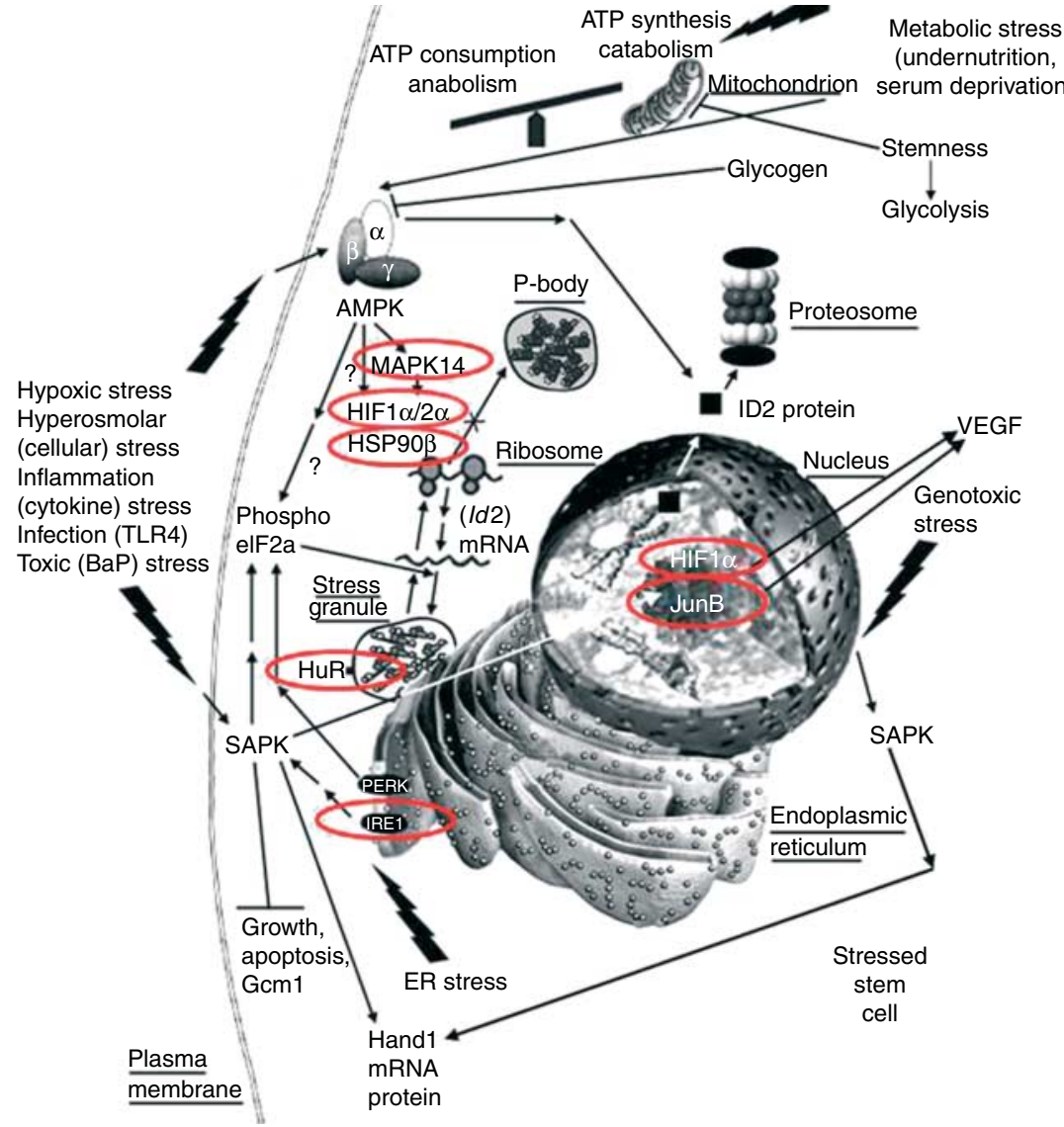

Figure 2 Multiple intracellular and extracellular stresses convert anabolism to catabolism, suppress apoptosis at low doses, and at high doses suppress growth and induce loss of potency factors and prioritized gain of early essential differentiation factors. BaP, benzopyrene; TLR4, toll-like receptor 4 , lipopolysaccharide receptor; Id2, inhibitor of differentiation 2; HuR, human antigen R; Hand1, heart and neural crest derivative inducer; Gcm1, glial cells missing 1; elF2a, eukaryotic translation initiation factor 2A; SAPK, stress-activated protein kinase; AMPK, AMP-activated protein kinase; aka Jun kinase, MAPK8/9; PERK, PKR-like ER kinase; IRE1, inositolrequiring enzyme 1 . Red ellipses show placental stress null lethals discussed in Table 1 and in the text (JunB). The rough endoplasmic reticulum and nuclear figures were used with kind permission of Molecular Expressions (http://micro.magnet.fsu.edu) and the proteasome figure was used with kind permission of wikipedia (http://en.wikipedia.org/ wiki/Proteasome) and occurs during an earlier formative period of the mouse labyrinth structure compared with the induction of elevated PERK1 in later preeclamptic human placenta. It indicates that IRE1 is activated by hypoxic stress in mouse and acts to regulate vascularization of the labyrinth during placentation to provide sufficient gas/ nutrient exchange. Taken together with the interpretation of human data, it suggests that the IRE1 sensor receives normal hypoxic signals to feed forward into trophoblast development, but elevated stress signals lead to slower anabolism and labyrinthine growth. In other words, IRE1 and ER stress mechanisms are part of the developmental plasticity shared by normal and pathogenic responses early and late in placental development.

The similar requirements during placental development for p38MAPK $\alpha$ (aka MAPK14), HIF1 $\alpha / 2 \alpha$, and its requisite heterodimer partner HIF1 $\beta$ (aka hypoxia-inducible factor $1 \alpha / 2 \alpha$ and HIF1 $\beta$ /ARNT respectively) has been reviewed elsewhere (Rappolee 2007). Interestingly, MAPK $14 \alpha$ is much more highly expressed than other p38MAPK isoforms (p38MAPK $\delta$ / MAPK13 and p38MAPK $\gamma /$ MAPK12) in preimplantation mouse embryos (Zhong et al. 2004) (Table 1, Fig. 2).

Although it is not known whether MAPK $14 \alpha$ is the dominant isoform in first-trimester human placenta, for the SAPK/JNK subfamily of the MAPK superfamily,
SAPK/JNK2 (MAPK9) is the dominant isoform (compared with JNK1/MAPK8 and JNK3/MAPK10) in mouse preimplantation embryos and in weeks 5-7 human villous explants. In early postimplantation mouse, MAPK9 is the dominantly expressed form of the SAPK/JNK subfamily of MAPK and contributes to hyperglycemia-induced diabetic embryopathy in a mouse model for diabetes (Yang et al. 2007, 2008a). Thus, for MAPK9, dominant expression before and after implantation is correlated with dominant mediation of diabetic stress effects early after implantation. By expression and function, it is likely that for the p38MAPK subfamily, MAPK14 is dominant in humans in the early first-trimester placenta.

MAPK14 and HIF1 $\beta$ null mouse mutants develop lethal placental phenotypes that are phenocopies. Similar to the IRE1 null mutant phenotype, the null mutants for MAPK14 and HIF1 $\beta$ or HIF $1 \alpha / 2 \alpha$ have a deficiency in labyrinthine villous core vascularization. MAPK14 nulls fail to develop sufficient labyrinthine vasculature and this results in apoptosis and labyrinthine failure by E9.5, earlier than the IRE1 null mutant failure (Mudgett et al. 2000). Mouse ARNT null embryos have insufficient vascularization of the yolk sac and labyrinthine villous mesenchyme and die by E10.5, and ARNT null ESC chimeras are normal while ARNT null 
lethality is prevented by tetraploid fusion rescue (Maltepe et al. 1997, Adelman et al. 2000a). Both AMP-activated protein kinase (AMPK) and MAPK14 (which is often downstream of AMPK) are known to activate HIF in other cell models (Xie et al. 2011). It is likely that HIF is required in TSC-derived placental ectoderm of the villi to induce vascularization of the ESC-derived mesenchymal core, which does not require HIF.

The common phenotype for MAPK14 and HIF1 is hypoxia-induced placental ectoderm-to-mesenchyme signaling to induce vascularization (Adelman et al. 2000a, 2000b, Mudgett et al. 2000, Cowden Dahl et al. 2005, Maltepe et al. 2005). HIF is required for normal spongiotrophoblast lineage and subsequent production of invasive TGC. But the initial requirement is for normal mesenchymal invasion of the chorion and its vascularization. Labyrinthine villous vascular failure is dominant although spongiotrophoblast and invasive TGC are also partially reduced in the HIF1 $\beta /$ ARNT nulls.

HIF functions have been most-studied during responses to hypoxic stimulation. However, it should be noted that HIF $1 \alpha / 1 \beta$ gene products are induced and have essential functions when fibroblast growth factor 4 (FGF4) is removed and cultured mouse TSC differentiate normally at ambient $\mathrm{O}_{2}$ levels (Maltepe et al. 2005). The lineage-governing effects of HIFs during normal differentiation or hypoxic differentiation are different in quantity and quality (Maltepe \& Simon 1998, Cowden Dahl et al. 2005, Maltepe et al. 2005), suggesting that HIFs are part of a developmentally plastic program to create placental and labyrinthine function. HIF is important in normal mouse TSC differentiation in mediating lineage choice. But HIF acts to maintain potency and block differentiation when hypoxic stress elevates as $\mathrm{O}_{2}$ levels drop below the optimum for TSC proliferation and potency at $2 \% \mathrm{O}_{2}$.

HuR is another multifunctional protein that is induced by many stresses with pleiotropic effects, the most important involves the elF2a phosphorylation event (Kedersha \& Anderson 2002; Table 1, Fig. 2). The activation of the HuR response can occur via oxidative or ER stress through IRE1 and PERK. This leads to the transition of mRNA from active ribosomes to inactive HuR-positive stress granules where the mRNA is protected (Anderson \& Kedersha 2008). This saves large amounts of energy after stress subsides, and existing mRNA returns to the ribosomes from stress granules. An alternate strategy would be to destroy mRNA during stress and re-synthesize it after stress; but destruction and resynthesis of mRNA require large amounts of energy. For an implanting conceptus with large energy requirements for proliferation and differentiation, protecting mRNA during stress is a key function. The mouse HuR knockout is a placental lethal with failure to initiate the mesenchymal interdigitation into the chorion at chorioallantoic fusion (Katsanou et al.
2009). It results in an early initiation of dysfunction at E8.5-9.0. Use of conditional Cre-lox-driven recombination showed that only trophoblasts required HuR, not villous mesenchyme and endothelium. HuR is mostly cytoplasmic in villous placental epithelium where it might be involved with stress granules. The HuR null mutant conceptuses developed normal spongiotrophoblasts and trophoblast giant cells (TGCs) and only the chorionic interaction with the allantois was faulty. An important defect was the failure of the allantoic mesoderm to vascularize. Thus, like IRE1, MAPK14, and HIF1 $\beta$, HuR is a stress response gene that is necessarily activated in the chorionic epithelium to develop and vascularize mouse labyrinthine mesenchymal cores.

Interestingly, we have shown that stress induces a reversible decrease in mouse TSC accumulation rates and an $\sim 80 \%$ loss of ID2 protein (Zhong et al. 2010). ID2 protein loss is proteasome-dependent and not dependent on mRNA loss. However, Id 2 mRNA is retained at $100 \%$ of unstressed levels (Liu et al. 2009) during the $\sim 80 \%$ loss of ID2 protein. Thus, it is possible that the essential role of HuR (Mazroui et al. 2007) is in the reversible adaptation to stress by preserving mRNA like $I d 2$ in stress granules for use in new translation once the stress subsides. Hypoxic stress at $<2 \% \mathrm{O}_{2}$ is likely to subside at E9.5 in mice when fetal oxygen rises sharply and indicates that both maternal and fetal placental vascularization is in full operation.

Heat-shock protein $90 \beta$ (HSP90 $\beta$ ) is a master HSP epistatically near to end function and the mouse HSP90 $\beta$ null mutant generates placental lethality due to labyrinthine vascularization failure at E10.5 (Voss et al. 2000; Table 1, Fig. 2). Although HSP90 $\beta$ is expressed ubiquitously, chimeric analysis of the null mutant showed that the primary failure occurred when the mutant was in the allantois and mesenchymal core, not the epithelium. Lack of HSP9O $\beta$ in the labyrinthine mesenchyme indirectly led to incomplete differentiation of the placental epithelium and decreased expression of epithelial VEGF. Thus, failure of the mesenchymal trigger resulted in a decreased epithelium VEGF similar to the other null mutants we have discussed whose direct effects were in the chorionic epithelium.

The human embryo implants at the end of the third week of pregnancy, the chorion develops by the fourth week, is invaginated by allantoic mesoderm by the fifth week, and the mesodermal core vascularizes by the sixth week with villous branching continuing for some time (Schoenwolf \& Larsen 2009). These events occur during days E8.0-10.5 in mouse with labyrinthine branching continuing for some time thereafter (Watson \& Cross 2005). In mice with proliferation defects like the retinoblastoma $(\mathrm{Rb})$ null mutant, a relative increase in labyrinthine villous vascular density can compensate for the excessive trophoblast proliferation and reduced labyrinthine branching (Watson \& Cross 2005). However, most mouse null mutants with a small labyrinth cannot 
compensate with increased vascular density. Perhaps like the null lethals here, this is due to an inability to secrete sufficient angiogenic VEGF. Taken together, the interpretations of defects in null mutants in stress genes in mice would indicate a development of insufficient villous function in humans within 2 weeks after implantation, early in the first-trimester. Hypomorphic alleles for similar genes functioning in humans or elevated levels of stress might lead to non-lethal effects that would ramify into the second and third trimester, especially if further stress episodes occur during these later periods.

In the mitofusin 2 (Mfn2) knockout, there was a failure of the placenta to make TGC at the maternal-placental interface, and these cells were not endoreduplicated to produce giant nuclei (Chen et al. 2003; Table 1). The Mfn2 null mutant mice were smaller by E8.5. There was no resorption through E10.5 but it accelerated after this. The authors suggested that of all placental lineages, parenchymal function or endoreduplication may require the most ATP and this requires fused, tubular mitochondria. However, hyper-fusion of mitochondria mediated by Mfn2 is also required for cyclin E expression (Mitra et al. 2009) and cyclin E is required for endoreduplication in the mouse (Geng et al. 2003, Parisi et al. 2003). Thus, endoreduplication is also a likely mechanism that is dysfunctional in Mfn2 and leads to lethal deficiency in TGC function.

How does mitochondrial function relate to pathogenic responses in stressed, placental stem cells? We have defined the optimal niche for maintaining mitotic, multipotent, TSC culture with potency- and proliferation-maintaining FGF4 (Chai et al. 1998, Tanaka et al. 1998). Oxygen at $2 \% \mathrm{O}_{2}$ is the niche for highest potency and proliferation and lowest stress as denoted by minimal activation of MAPK8/9 (Zhou et al. 2011). This niche may be at the physiological $\mathrm{O}_{2}$ level at the implantation site in humans and is implicated as the niche for many adult stem cells. In contrast, $0.5 \% \mathrm{O}_{2}$ was found to support the highest level of three transcription factors that mediate differentiation and the lowest level of three transcription factors that maintain TSC potency. This suggests that hypoxic stress would initiate differentiation in mouse TSC despite the presence of FGF4 that suppresses differentiation. We have shown that hyperosmolar (cellular) and benzopyrene (genotoxic) stress are dominant over FGF4 for inducing initiation of differentiation (Abdallah et al. 2009, Xie et al. 2010, 2013, Zhong et al. 2010, Awonuga et al. 2011). Thus, many types of stress may act during early placental development to decrease potency and increase differentiation.

Paradoxically, hypoxia at $0.5 \% \mathrm{O}_{2}$ initiates the highest differentiation after 1 day despite the presence of FGF4 (Zhou et al. 2011) but cannot sustain sufficient mitochondrial function after 7 days to complete terminal differentiation despite FGF4 removal (Rappolee et al. 2011a). We think of the FGF4 present for $24 \mathrm{~h}$ as a preimplantation model and the FGF4 removal for 7 days as a postimplantation model. Taken together, the markers used to test hypoxic stress in the cultured mouse TSC model implicate the early postimplantation in vivo events that are targeted by $5 / 6$ null lethal placental stress gene phenotypes in Table 1 . Thus, both in vitro hypoxia at $0.5 \% \mathrm{O}_{2}$ and null lethal placental stress genes produce labyrinthine surface lineage defects.

We have shown that hyperosmolar stress induces TSC differentiation to primary TGC and suppresses later lineages, but these studies were performed at 20\% $\mathrm{O}_{2}$ (Liu et al. 2009, Zhong et al. 2010, Awonuga et al. 2011, Xie et al. 2013). Hyperosmolar stress that induces high differentiation at $20 \% \mathrm{O}_{2}$ cannot increase differentiation at $0.5 \% \mathrm{O}_{2}$ (Rappolee et al. 2011a). Thus, low $\mathrm{O}_{2}$ at $0.5 \%$ cannot support differentiation induced by hyperosmolar or hypoxic stress.

Terminal differentiation markers most affected by mitochondrial antagonists at $20 \% \mathrm{O}_{2}$, a mitochondrial agonist at $2 \% \mathrm{O}_{2}$, and hypoxia at $0.5 \% \mathrm{O}_{2}$ are placental lactogen 2 (PL2), cathepsin (Cts)q, and syncytin A. The former two markers identify sinusoidal TGC and the later marker identifies the syncytiotrophoblast A layer (Simmons \& Cross 2005, Simmons et al. 2007). As these two lineages make up the surface of the labyrinthine placenta (Maltepe et al. 2010), it appears that this is intrinsically the most $\mathrm{O}_{2}$-sensitive progeny of mouse TSC. Thus, in the in vitro model, abnormally low $\mathrm{O}_{2}$ stress strongly targets two lineages at the surface of the labyrinthine placenta when hypoxia is so great that it overwhelms normal stress response mechanisms. This is consistent with the finding from the five out of six placental stress gene null lethals that target the surface of the labyrinthine placenta when normal, low implantation site $\mathrm{O}_{2}$ (presumably $\sim 2 \%$ ) overwhelms response mechanisms made abnormally insufficient by knocking out key stress responses.

ROS develop during hypoxia but also as $\mathrm{O}_{2}$ levels rise or inflammatory ROS occur and becomes especially high as mitochondria become active during stem cell differentiation. An additional question that will be addressed below is whether other stresses of the endometrium beside hypoxia may lead to placental stem cell depletion and lineage imbalance in vivo.

In summary, Table 1 provides several clues to understand the role of stress in normal vascularization of the labyrinthe. It also shows the developmental plasticity may rescue this function during stress, or fail and lead to pathology. These null mutants indicate that hypoxic stress regulates normal development. The null mutants also indicate that stress mechanisms maintain stem cells during stress while adjusting differentiation in response to stress.

The increase in fetal mouse $\mathrm{O}_{2}$ levels at E9.5 indicates that the placental $\mathrm{O}_{2}$ exchange is fully functional at the level of transfer from the labyrinthine surface to villous core vasculature (Mitchell \& Yochim 1968, Fischer \& 
Bavister 1993). This is probably similar to the end of the first-trimester in humans when the trophoblast plug blocking the spiral artery is broken and the villous surface is first bathed in maternal blood (Burton et al. 2010). It is significant to note that the three lethal mouse null mutant phenotypes begin before E8.5, in a period similar to the early first-trimester in humans before the plug breaks and maternal blood bathes the labyrinthine surface. Considering the early mouse null mutant phenotypes together with the later-developing human placental oxygenation, this suggests that diseases of placental insufficiency (e.g. intrauterine growth restriction (IUGR), preeclampsia) that present clinically in the second and third trimester may have their origins in early first-trimester.

It is also significant that three of five of the lethal mutant phenotypes of the labyrinthine vascularization have a defect in VEGF production by the labyrinthine epithelial cells. Expression analysis and elegant experiments using ESC chimeras, tetraploid fusion rescue, and inducible promoters for labyrinthine mesenchymal core or epithelium shows that four lethality phenotypes are due to function in the epithelium, but even the mesenchymal deficiency leads to reduced VEGF production by the epithelium.

Although five null labyrinthine placental lethal mutants is a small fraction of all placental null lethal mutants, it is a high fraction of placental stress pathway null lethals (five out of six). Bolstering the five null mutants are additional mutants like JunB (discussed later), which were not classified as a 'stress' pathway genes by their authors but classified as such by others in the field. In addition, gestational hypoxia induces increased trophoblast invasion but also diminishes the labyrinthine layer of the rodent placenta (Rosario et al. 2008). Moreover, data from our laboratory that models hypoxic stress effects in cultured mouse TSC pinpoint severest hypoxic suppression of the syncytiotrophoblast A layer and sinusoidal TGC (Zhou et al. 2011, Rappolee et al. 2011a), both cell lineages at the surface of the labyrinthine placenta. Also nearly all the hypoxia-induced, VEGF-regulating genes from Table 1 are necessary in placental developmental, suggesting that stress is a normal part of labyrinthine development. Thus, several lines of evidence suggest that hypoxia arises normally and regulates many genes that are necessary in regulating the cell lineages at the surface of the mouse labyrinthine placenta.

Together, data from the null mutants, gestational hypoxic stress studies, and analysis of the effects of hypoxic stress during differentiation of cultured TSC support the hypothesis that stress causes deficits of labyrinthine function. This is a primary type of placental insufficiency and originates well before function is activated at E9.5 and suggests that function does not arise before stress but because of stress. Pathology would occur when elevated stress hyperactivates the normal response but depletes stem cells due to stress-induced differentiation or apoptosis in human placental pathology (Xie et al. 2011, Longtine et al. 2012, Rappolee et al. 2012). The mouse placental null mutant genes in stress pathways that are lethal in normal vivarium indicate that stress arises during normal development.

\section{Null mutants that are not lethal until the gestational females are stressed}

A separate category is composed of null mutants with normal or near normal fertility until the pregnancy is stressed (Table 2). Trophoblast prolactin-like protein A (PLPA) and decidual prolactin-related protein are necessary in the response to gestational hypoxia in mouse (Ain et al. 2004a, Alam et al. 2007) but have no or only minor phenotypes without gestational stress. These prolactin-related proteins are required from E9.5 to 11.5 and both act on mesometrial and decidual responding cells that are needed for chorioallantoic placental development.

The peroxiredoxin 6 (PRXD6) null is not an embryonic lethal, but the immunophilin FK506-binding protein 52 (FKBP52) null is an implantation lethal due to insufficient progesterone signaling and insufficient antioxidant

Table 2 Stress enzyme and other stress mediators are important in placental development, as illustrated by null mutants that show or increase lethality during stressed pregnancies ${ }^{\mathrm{a}}$.

\begin{tabular}{|c|c|c|c|}
\hline \multirow[b]{2}{*}{ Stress gene } & \multicolumn{2}{|c|}{ Earliest noted deviation } & \multirow[b]{2}{*}{ Reference } \\
\hline & $\begin{array}{l}\text { Onset, site of placental, } \\
\text { decidual expression }\end{array}$ & $\begin{array}{l}\text { Onset, cause of lethality } \\
\text { during elevated stress response }\end{array}$ & \\
\hline$D P R P$ & $\begin{array}{l}\text { Decidua expression initiates by E5.5- } 6.5 \\
\text { Hypoxia induced deviation by E9.5 }\end{array}$ & $\begin{array}{l}\text { Insufficient response to hypobaric } \mathrm{O}_{2} \text {, failure in } \\
\text { mesometrial decidua, chorioallantoic placenta }\end{array}$ & Alam et al. (2007) \\
\hline PLPA & $\begin{array}{l}\text { Labyrinthine trophoblasts peak expression } \\
\text { E10.5 normally }\end{array}$ & $\begin{array}{l}\text { Irreversible collapse by E11.5 } \\
\text { Insufficient response to hypobaric } \mathrm{O}_{2} \text { and failure } \\
\text { of trophoblast to NK maternal response and } \\
\text { labyrinthine response E9.5 }\end{array}$ & Ain et al. (2004a) \\
\hline PRDX6 (FKBP52 $\left.2^{-/-}\right)$ & $\begin{array}{l}\text { Decidua expression peaking at } \\
\text { E8.0 normally }\end{array}$ & $\begin{array}{l}\text { Insufficient response to oxidative stress to E4.0 } \\
\text { injection of paraquat } \\
\text { Failure of blastocysts to implant by E5.0 }\end{array}$ & Hirota et al. (2010) \\
\hline
\end{tabular}

DPRP, decidual prolactin-related protein; FKBP52, FK506-binding protein 52; PRDX6, peroxiredoxin 6; PLPA, prolactin-like protein A.

aPLPA suppresses maternal NK feedback on villous epithelial development and mesometrial invasion. 
effects of FKBP52-dependent PRXD6 (Hirota et al. 2010; Table 2). When paraquat is used to induce oxidative stress, it is likely that the insufficient antioxidant capacity of PRXD6 in the endometrial implantation site in FKBP52 nulls is the cause of severe loss of the implanting embryo.

These null mutants show that stress response pathways exist that are not essential until stress becomes elevated above normal levels. It is likely that many other stress response genes under study, such as MAPK8/9, have essential function during placental development under normal conditions but become essential under hypoxic and other types of stress.

\section{Stress can serve as an endogenous inducer of normal placental development, but at higher exposures becomes pathogenic}

The null mutant lethals discussed here are catastrophic outcomes that illustrate the essential role of a gene in a normal process that includes stress. The catastrophes are due to missing copies of both alleles due to experimental manipulation in the mouse. If both alleles were dysfunctional in humans, the catastrophic end of a continuum of development plasticity would be spontaneous miscarriage. More numerous, lesser pathologies constitute the lesser range of the continuum. These would result due to a combination of genetic heterozygous loss or less functional alleles and/or greater or repeated hypoxic stress (or other stresses that diminish stem cell population expansion). Hypofunctional alleles and repeated hypoxic stress that overwhelms the response mechanisms should cause runting, incomplete parenchymal function, lineage imbalance, stem cell depletion, and epigenetic changes. The lesser range of the continuum might include non-lethal pathologies such as preeclampsia or IUGR in humans.

The null lethal mutants suggest an interpretation that is significant to developmental plasticity. They support the second-alternate hypothesis from the Introduction section: 'need arises before function and stress signals are part of the normal stimuli that regulate developmental mechanisms'. Endogenous stresses proportionally modify essential developmental programs that make the labyrinthine placenta. In this case, hypoxia arises before placental function and this is the apparent stress for the five placenta null lethals analyzed here. Thus, the mechanisms shown by the null lethals must be in place to respond to normal stress. These mechanisms can be overwhelmed by high stress exposures, but interesting sublethal responses are likely to require central regulation by stress enzymes that control many of their short- and long-term outcomes.

Shallow invasion is a hallmark of placental pathogenesis and is also regulated by oxygen levels in mouse and human (Jauniaux et al. 2006, Rosario et al. 2008,
Pringle et al. 2010), so it is not clear why this literature screen did not also reveal a cluster of null mutants that affect invasion. It could be that mouse invasion is shallow compared with human (Carter 2007) and no null mutation is lethal because it limits an already shallow invasion.

A defect in the methodology we used is that the null mutant gene may not be identified as a 'stress' gene by the EndNote search engine. For example, the activator protein 1 (AP1) heterodimeric signaling complex is versatile in inducing or suppressing growth (Shaulian \& Karin 2002). In the AP1 complex, JunC mediates mitogenic signaling and JunB mediates SAPK- and p38MAPK-induced suppression of growth during inflammatory and genotoxic stress. The mouse JunB null described previously creates lethality between E8.5 and 10.0 due to placental failure to induce vascularization of the decidua and the labyrinthine core (Schorpp-Kistner et al. 1999). But the authors did not classify JunB as a stress gene. The significance of this is that JunB is a stress response factor that enables labyrinthine epithelium early on to induce maternal decidual vascularization as well as mesenchymal core. In addition, hypoxia induces VEGF through collaborative binding of AP-1/JunB and HIF1 $\alpha$, so JunB contributes to intercellular vascular induction (Schmidt et al. 2007). Thus, JunB should be considered as a sixth stress gene, of seven considered here, that mediates essential differentiated function of the labyrinthine epithelium in response to hypoxic stress.

Although several lines of evidence from the rodent models suggest that stress guides normal labyrinthine placental development and pathogenically imbalance this development at high exposures, some cautionary notes need to be mentioned. One is the large expansion of prolactin-like genes in large-litter-size rodents (Wiemers et al. 2003, Soares et al. 2007) that make rodents unique compared with humans. The other important reservation for interpreting data is that rodents (especially mice) have high surface-to-volume ratios and low fat reserves and are therefore much more susceptible to nutrition imbalances and stress than mammalian models such as humans and large farm mammals (Krasnow \& Steiner 2006). But this suggests that aspects of the stress response will have larger emphasis in mouse, not that lessons learned in mouse are incorrect.

Some data have been gathered in humans that support the stress model of placentation. For example, two of three maternal stress hormones increased human chorionic gonadotrophin (hCG) secretion/stressed human trophoblast cells during culture (Tal et al. 1991). But diminished cellular growth was not tested in these studies. Tong et al. (2006) found that very early postimplantation hCG levels can predict miscarriage much later; 'The mechanisms underlying late first- and second-trimester miscarriages may have begun as early as the first week of implantation'. In humans a diagnostic 
of successful pregnancies in the normal population or following IVF, is the continuing, sequential increase in hCG early after implantation (Seeber 2012). Although there are many differences between hCG in humans and PL1 in mice, both increase rapidly after implantation, are upregulated by similar transcription factor subsets (Cross et al. 2002, Roberts et al. 2004), bind receptors in the corpus luteum that lead to progesterone secretion, and contribute strongly to maintenance of early implanted conceptuses. Thus, it can be anticipated that the compensatory and prioritized differentiation that is a response of stressed, cultured mouse TSC and features PL1 induction will occur in vivo during gestational stress in rodents and humans.

Well-planned studies are needed to test whether stress induces early placental hormones in vivo in mice and whether they are preferentially induced by stress in humans. Stress decreases placental stem cell population expansion and this would reduce total hormone production, although it increases the ratio of hormones to cells during compensatory differentiation (Zhong et al. 2010, Awonuga et al. 2011). Studies of placental hormone production in vivo do not normalize hormone production to the size of the conceptus or placenta. Cultured human villous explants or first-trimester cell lines would enable the highest accuracy of tests of compensatory and prioritized differentiation. Unfortunately, the earliest villous explants may be too late to assay early postimplantation stress effects and human trophoblast cell lines are limited in their potency compared with mouse TSC.

\section{What are the endometrial stress signals that can initiate early stress responses that include placental stem cell lineage imbalance and stem cell depletion?}

\section{There are stress inputs from the endometrium to placental surface}

Placental dysfunction and death may result from a direct attack on placental surface by intolerant maternal immune and non-immune cells (Myatt \& Miodovnik 1999, Schiessl 2007). Indirect negative, stressful stimuli by second-hand cytokine signaling by maternal cells, hypoxia, infection, and other inflammatory signals are received by and harm placental cells (Red-Horse et al. 2004a, 2004b). Aside from leukemia inhibitory factor, colony stimulating factor 1 (CSF1), and granulocyte-monocyte-CSF, which we reviewed previously (Rappolee 2007, Xie et al. 2011), other maternal and fetal ligands mediate implantation. Ligands that signal through specific receptors coupled with gp130 are important in signaling trophectoderm before and after implantation. These ligands include interleukin 11 (IL11), C-X3-C motif ligand 1 (CX3CL), and C-C motif ligand 14 (CCL14) and are important in the human midsecretory phase, and IL11 is essential in mouse implantation (Robb et al. 1998, Ain et al. 2004b, Salamonsen et al. 2007, Dimitriadis et al. 2010). Much of the function of these ligands is to directly support decidual and natural killer cell development and regulate trophoblast development and migration. However, these ligands also regulate trophoblast responses such as adhesion and migration but are not stressful in terms of decreasing proliferation. Interestingly, in humans, progesterone signaling can be blocked by MAPK $8 / 9$ activity and MAPK $8 / 9$ signaling must remain attenuated for decidualization to continue successfully (Leitao et al. 2010). We think that placental dysfunction, also mediated in part by MAPK8/9 signaling, due to indirect effects of maternal cytokines, can lead to insufficient placental development and ensuing preeclampsia and IUGR.

In the two-stage theory of preeclampsia, initial dysfunction is in the trophoblast lineage. But this dysfunction can be triggered by endometrial dysfunction. The major cause of preeclampsia is the shallow placental invasion of the endometrium that leads to lower blood and $\mathrm{O}_{2}$ flow to the placental exchange surface (Chakraborty et al. 2002, Myatt 2002, Knofler 2010). This occurs when insufficient placental invasion and trophoblast endo-vascularization of maternal spiral arteries leads to abnormally high resistance to maternal blood flow and resulting insufficient blood flow to the placental surface. A second cause is the failure of proper placental exchange functions at the surface of the labyrinthine placenta and insufficient vascularization of the villous core in humans (Burton \& Jones 2009).

Thus, placental dysfunction results from a failure to bring maternal blood to the placental surface or a failure at the surface to mediate sufficient nutrient/gas exchange. If the development of the villous exchange surface is sufficient and normal, then insufficient development of maternal blood delivery is dominant and severe forms of preeclampsia and IUGR can develop (Burton et al. 2010, Maltepe et al. 2010). However, if maternal blood delivery is normal and sufficient, malformation of the epithelial surface or mesenchymal core of the labyrinthine placental can still lead to less severe forms of preeclampsia and IUGR as well as more severe forms (Myatt \& Webster 2009).

The data in Table 1 indicate that normal levels of stress are sensed by the developing labyrinthine placenta and mediate aspects of vascularization. Higher levels of stress would truncate this program by decreasing stem cell growth and increasing the essential program of vascularization and hormone production by the human villous epithelial cells. A less extensive villous layer of the labyrinth occurs in a normal vivarium with the mouse $\mathrm{Rb}$ null, which appears to increase vascularization in compensation for decreased size, but most nulls with reduced labyrinths do not compensate by increasing vascularity (Watson \& Cross 2005). The amount of vascularity is proportional to the size of the placenta. 
However, it is possible that adjacent maternal vascularity did increase, especially in the lacunar stage, early after implantation. During this period of early rapid TSC expansion, increased maternal vascularity could compensate for insufficient placental function.

One pathogenic hallmark of preeclampsia is the elevation of 'syncytiotrophoblast' fragments shed from the villous epithelial surfaces into maternal blood during human pregnancy. Recent data suggest that the interdigitated villous epithelial cytotrophoblast stem cells are more sensitive to stress than syncytiotrophoblasts and produce apoptotic fragments (Longtine et al. 2012). Our mouse model suggests that stress induces compensatory and prioritized differentiation that causes depletion of stem cells. Thus, a common tendency in early mouse trophoblast development and later human villous development is that essential parenchymal function is maximized at the expense of stem cell depletion. Stem cell depletion is coupled with differentiated syncytiotrophoblast function in humans and PL1 production in mouse. This strategy may improve immediate survival but sacrifice later developmental necessities that depend on stem cells. These assertions are based on strong preliminary studies but require careful analysis to establish whether early human placental stem cells are depleted by stress in favor of differentiated early functions such as hCG production.

\section{Theories of stress-induced compensatory and prioritized differentiation of placental stem cells help explain how an adaptive stress response can become pathogenic}

In the British Broadcasting Corporation program The Human Body; Part 2 of 7, An Everyday Miracle, Robert Winston addressed the great loss of embryonic life in humans:

'So why has it been so tough to get this far (into late pregnancy)? The easy answer is that our bodies are riddled with imperfections, right from the start. Sperm so weak, they are all but annihilated. Eggs so fragile they only live for a day. But the bigger question is, 'why are we like that?' Why are our bodies designed to make each stage of pregnancy so difficult and so dangerous? And of course that is the whole point; our bodies are not designed at all. Instead we have evolved. Our imperfections are simply problems inherited from our ancestors. The great triumph is that we have also inherited the solutions.'

From our standpoint, some of the inherited solutions are the stress-enzyme-mediated responses in mouse that have evolved to mediate stem cell survival at low stress exposures and organismal survival at higher exposures (through compensatory and prioritized differentiation). Thus, stress enzyme-mediated solutions have been selected during evolution and we study the solutions that have overcome transient stress and enabled the transmission of genetic programs into the next generation.

From the stem cells' perspective solving dosedependent problems is straightforward; increasing doses activate more enzyme and thus more enzymedependent control of metabolism, survival mechanisms, and differentiation mechanisms.

However, the time-dependent problems of stress are intrinsically problematic. Some stresses may have characteristic durations, but in the final analysis, stem cells cannot estimate the duration of a stress. Thus arises the ultimate solution and flexibility; stress can induce nearly all mouse placental stem cells to differentiate to provide one early differentiated function and to completely suppress a later function (Rappolee et al. $2011 a, b$, 2012; Fig. 1). Failure to produce sufficient early function produces immediate death. Later death is unpredictable but reversibility of differentiation or sequential differentiation, from one differentiated state to a second one, may produce later essential functions (Zhong et al. 2010, Rappolee et al. 2012). Reversibility is the prime mechanism to recover after stress induces stem cells to lose potency and pseudo-differentiate.

We have reported the new theories that stressed mouse stem cells differentiate when stress reaches a magnitude and duration that decrease stem cell accumulation (Xie et al. 2011, Rappolee et al. 2012; Fig. 1). We call this 'compensatory differentiation' as more differentiated function is induced in fewer cells (Fig. 1, examples 2, 3 and 4). Stressed murine (mu)TSC and muESC undergoing compensatory differentiation induce the first, essential lineage and suppress later, essential lineages. In mouse TSC and ESC, we call this 'prioritized differentiation' (Fig. 1, examples 3 and 4) due to the emphasis on early differentiated function (Rappolee et al. 2012). Stressed stem cells of the implanting embryo have only a stem cell survival response at low stress doses but develop an organismal survival response of prioritized differentiation at higher exposures that slow cell growth.

The significance of stress-induced prioritized differentiation is that it is a hallmark of pathogenic development. It occurs when stem cell populations of the implanting embryo become depleted and differentiation becomes imbalanced. This may provide for early functional needs while leaving later essential differentiation in deficit were stress to continue. Trophoblast lineage imbalance is thought to contribute to preeclampsia, perhaps as early as the mid-first trimester (Roberts \& Hubel 2009). A more speculative model has peri-implantation imbalance (Huppertz 2008) leading to preeclampsia or IUGR. The analysis of null mutants of genes in stress pathways indicates that stress induces endogenous pathways of mouse placental development before full placental $\mathrm{O}_{2}$ delivery at E9.5. 
When we use a stressed mouse TSC model are we modeling later mouse developmental responses and human second-trimester defects, first-trimester defects, or both? Primary TGC are derived from the implanting mouse blastocysts and is the first lineage arising from cultured TSC when FGF4 is removed or stress added. Thus, this culture system is a model of normal and stressed differentiation soon after implantation.

During normal human placental development, stem cell proliferation occurs at high velocity during the first trimester when the stem cells are behind the endovascular plug where $\mathrm{O}_{2}$ levels are low (Burton et al. 2010). Some cytotrophoblasts invade toward the higher $\mathrm{O}_{2}$ levels of the mesometrial endometrium and these differentiate to increase invasiveness. Differentiated lineages also produce factors that promote maternal vascular angiogenesis and permeability with the aim of increasing the vascular supply to the conceptus.

One type of abnormal human placentation occurs because of signals in the endometrial milieu, which creates placental stress, both for stem cells and differentiating placental cells (Burton et al. 2010). Inflammation, infection, hypoxia, and/or under-nutrition lead to a decrease in macromolecular synthesis such as translation. This suppresses growth pathways such as $\mathrm{Akt} / \mathrm{mTOR}$ and suppresses proliferation of endometrial cells and placental cells in vivo. Although causation of conditions such as preeclampsia and IUGR are complex, shared mechanisms and effects between in vivo and in vitro models are significant (Burton et al. 2010).

\section{Cellular stress signaling pathways}

In cultured human cytotrophoblasts, and mouse TSC, placental cytokines produced by inflammation (TNF $\alpha$ ), toll-like receptor 4 stimulation, serum starvation, hypoxia, toxicants such as benzopyrene and dioxin, and hyperosmolar stress lead to activation of stress enzymes such as SAPK, decrease in macromolecular synthesis, and suppression of proliferation (Fig. 2; Zhong et al. 2007, 2010, Xie et al. 2008, 2010, Liu et al. 2009, Awonuga et al. 2011, Zhou et al. 2011). The stress enzymes our laboratory has studied most are stressactivated protein kinase protein (aka MAPK8/9, SAPK/ JNK1/2) and AMPK (aka AMPK $\alpha 1 / 2$, PRKAA1/2). These enzymes have complementary and integrated roles in the stem cell survival and organismal survival (prioritized differentiation) stress responses in cultured mouse TSC.

MAPK8/9 mediates rapid suppression of apoptosis in human first-trimester placental HTR but mediates increased apoptosis if stress persists at high enough levels (Zhong et al. 2007). In mouse, stress-induced, activated MAPK8/9 also transiently induces eomesodermin but chronically induces heart and neural crest derivative inducer 1 (aka Hand1) and Hand1-dependent PL1 (aka PL1, chorionic somatomammotropin/Prl3b1/
CSH1) (Awonuga et al. 2011). Thus, MAPK8/9 mediates stem cell survival and differentiation responses.

MAPK8/9 is activated in mouse and human placental cells in vivo and in vitro and plays a role in adhesion, invasion, survival, and apoptosis (Zhong et al. 2004, 2007, Cindrova-Davies et al. 2007, Kang et al. 2007, Lucchi \& Moore 2007, Xie et al. 2007, Yang et al. 2008b, Abell et al. 2009, Jessmon et al. 2010, Zhu et al. 2010). Unlike AMPK, SAPK has no role in mediating loss of potency factors in cultured mouse TSC (Abell et al. 2009) or ESC (Xu \& Davis 2010). However, when activated by the stress of cell culture, SAPK mediates choice of differentiated lineages in TSC and ESC (Abell et al. 2009, Xu \& Davis 2010, Rappolee et al. 2011a, 2011b).

AMPK is activated in placental cells by nutrient restriction in vivo (Ma et al. 2011) and benzopyrene, hyperosmolar stress, and adiponectin in vitro (Benaitreau et al. 2009, Xie et al. 2010, 2013, Zhong et al. 2010). In contrast, AMPK is suppressed in placenta during obesogenic diets (Zhu et al. 2009). Nutrient restriction and diminished ATP synthesis through serum deprivation in vitro hypersensitizes cells to hypoxic stress by activating as much AMPK in $20 \mathrm{~min}$ as is activated overnight when full serum is present (Liu et al. 2006, reviewed in Xie et al. (2011)). When AMPK suppression is reversed by an AMPK activator during an obesogenic diet, this reverses the generation of obesity (Baur et al. 2006), suggesting a causative role of AMPK in preventing anabolic activity. Thus, AMPK is activated by ATPdepleting stress stimuli in vitro and in vivo and causes a switch from anabolic to catabolic metabolism in attempt to replenish ATP.

In mouse, AMPK mediates rapid low-dose suppression of anabolic enzymes such as acetyl-CoA reductase (aka ACACA), which starts cell-autonomous anabolic to catabolic conversion (Zhong et al. 2010). But only at higher doses does AMPK cause loss of the TSC potency factor inhibitor of differentiation 2 (Id2). ID2 protein loss is necessary for normal TSC differentiation in mouse and cytotrophoblast differentiation in humans (Xie et al. 2011). Thus, at low stress exposures, AMPK mediates metabolic adaptation to stress, but at higher, proliferation-decreasing exposures, AMPK mediates differentiation by potency loss.

In mouse, stress induces rapid, transient AMPK activity that mediates loss of potency with reversibility as a key feature (Zhong et al. 2010). SAPK arises and attenuates much more slowly. During its longer activity, SAPK does not regulate potency but increases differentiation to an early, necessary lineage while suppressing later lineages (Zhong et al. 2007, Awonuga et al. 2011, Rappolee et al. 2011a). Other enzymes may play a role in TSC and other stem cells may use other enzymes to perform functions similar to those of AMPK and SAPK. But the kinetics of fast, reversible potency loss and slower prioritized differentiation gain are likely to be hallmarks of stress enzymes in the stress response of many types of stem cells. 


\section{Summary}

In this review, we examined general adaptive strategies and specific mechanisms of the stress response of placental stem cells. Stress is a part of normal development (Table 1). For at least some parts of development, as developmental needs occur before differentiated function, stress develops. This produces stress-induced regulation and modification of the developmental program. Many stress response genes, some probably in sequential pathways (Fig. 2), have been identified that mediate the role of stress in normal development. In addition, as these stress response pathways are present and necessary, they may also play key roles in the adaptation to elevated stress.

Supra-normal stress levels during gestation identify other genes (Table 2) that are not required for gestation in a normal vivarium. But in a stressed gestation, they are required to adapt the developmental program to successfully respond to elevated stress levels.

A brief examination of null lethals in Tables 1 and 2 raises several questions. Interestingly, the genes identified to date in the normal stress and elevated stress pathways are different. However, as normal and elevated stress are part of a continuum of developmental plasticity, it would not be surprising if null mutants for normal stress functions had different and earlier phenotypes if gestational null mutant females were stressed. Essential genes that mediate responses to elevated stress may superimpose on normal stress pathways and mediate greater function or may induce new adaptive responses not within the substrate range of the normal stress response genes.

Low $\mathrm{O}_{2}$ is the clearest example of a normal stress. Hypoxia below the $2 \% \mathrm{O}_{2}$ physiological optimum for potency/proliferation creates elevated stress. This exposure range for elevated hypoxic stress requires further study if we are to understand the pathogenesis of preeclampsia and IUGR. Reduced maternal leptin and increased maternal adrenaline and cortisol also slow stem cell growth and probably contribute to compensatory and prioritized differentiation. Other stresses, such as infection and inflammatory cytokines (from placental or maternal sources) create elevated stress in culture models of stem cells and should induce compensatory and prioritized differentiation. But this needs to be determined experimentally.

To understand the roles of compensatory and prioritized differentiation in humans, in vitro models using placental TSCs and ESCs are needed. One requirement is that these stem cells begin culture fully potent and then undergo normal and stress-induced differentiation in vitro. The other requirement is that we understand what the early, normal postimplantation events are and what the sequence of necessary events in humans (and nonhuman primates) is. Current human ESC lines are sufficient to begin testing for compensatory and prioritized differentiation, but human and non-human primate TSC are currently not fully sufficient. Promising human TSC are on the horizon and will probably be similar enough to mouse TSC to test our theories of stress responses.

It is of highest importance to understand how these mechanisms work during gestational stress in vivo and to understand how these mechanisms work in humans and non-human primates. Cultured, stressed stem cells can clearly make 'Faustian' bargains that at first seem suicidal. Stressed stem cells have the capacity to almost completely activate an early, essential lineage and completely suppress a later, essential lineage. But reversibility of differentiation toward potency is likely to rescue stem cells after short stress episodes. Some cases of preimplantation stress may be high enough to easily test early postimplantation differentiation choices and thus test these hypotheses in vivo.

Lurking in the Faustian bargain are the mechanisms of 'silent' changes in epigenetic memory that may ramify and emerge during later stresses and adaptations in pre- or postnatal life. SAPK is essential in the loss of the polycomb-mediated DNA methylation in two Drosophila stem cell types in response to two stress types (Lee et al. 2005, Owusu-Ansah \& Banerjee 2009). So, similar SAPK-dependent epigenetic changes should be induced by stress in mammalian stem cells. Together, the overt immediate effects on prioritized differentiation and possible silent epigenetic changes make for a potent brew of stress mechanisms. These mechanisms translate early stress in the peri-implantation conceptus to the progeny of stem cells throughout pre- and postnatal life.

\section{Declaration of interest}

The authors declare that there is no conflict of interest that could be perceived as prejudicing the impartiality of the review reported.

\section{Funding}

This was supported by a grant to DAR from NICHD, NIH (1R03HD06143102).

\section{Acknowledgements}

Thanks to Dr Sasha Drewlo, Dr Kezhong Zhang, members of the Rappolee Laboratory and to the Editors and reviewers at Reproduction for extensive comments on the text.

\section{References}

Abdallah M, Xie Y, Puscheck EE, Rappolee DA \& Awonuga AO 2009 Benzopyrene activates SAPK and induces HAND1 that favors differentiation of trophoblast stem cells. Fertility and Sterility 92 S136-S137. (doi:10.1016/j.fertnstert.2009.07.1208)

Abell AN, Granger DA, Johnson NL, Vincent-Jordan N, Dibble CF \& Johnson GL 2009 Trophoblast stem cell maintenance by fibroblast 
growth factor 4 requires MEKK4 activation of Jun $\mathrm{N}$-terminal kinase. Molecular and Cellular Biology 29 2748-2761. (doi:10.1128/MCB. 01391-08)

Adelman DM, Gertsenstein M, Nagy A, Simon MC \& Maltepe E 2000a Placental cell fates are regulated in vivo by HIF-mediated hypoxia responses. Genes and Development 14 3191-3203. (doi:10.1101/gad. 853700)

Adelman DM, Maltepe E \& Simon MC 2000b HIF-1 is essential for multilineage hematopoiesis in the embryo. Advances in Experimental Medicine and Biology 475 275-284. (doi:10.1007/0-306-46825-5_26)

Ain R, Dai G, Dunmore JH, Godwin AR \& Soares MJ 2004a A prolactin family paralog regulates reproductive adaptations to a physiological stressor. PNAS 101 16543-16548. (doi:10.1073/pnas.0406185101)

Ain R, Trinh ML \& Soares MJ 2004b Interleukin-11 signaling is required for the differentiation of natural killer cells at the maternal-fetal interface. Developmental Dynamics 231 700-708. (doi:10.1002/dvdy.20183)

Alam SM, Konno T, Dai G, Lu L, Wang D, Dunmore JH, Godwin AR \& Soares MJ 2007 A uterine decidual cell cytokine ensures pregnancydependent adaptations to a physiological stressor. Development 134 407-415. (doi:10.1242/dev.02743)

Anderson P \& Kedersha N 2008 Stress granules: the Tao of RNA triage. Trends in Biochemical Sciences 33 141-150. (doi:10.1016/j.tibs.2007. 12.003)

Awonuga AO, Zhong W, Abdallah ME, Slater JA, Zhou SC, Xie YF, Puscheck EE \& Rappolee DA 2011 Eomesodermin, HAND1, and $\mathrm{CSH} 1$ proteins are induced by cellular stress in a stress-activated protein kinase-dependent manner. Molecular Reproduction and Development 78 519-528. (doi:10.1002/mrd.21342)

Back SH, Schroder M, Lee K, Zhang K \& Kaufman RJ 2005 ER stress signaling by regulated splicing: IRE1/HAC1/XBP1. Methods 35 395-416. (doi:10.1016/j.ymeth.2005.03.001)

Barak Y, Nelson MC, Ong ES, Jones YZ, Ruiz-Lozano P, Chien KR, Koder A \& Evans RM 1999 PPAR $\gamma$ is required for placental, cardiac, and adipose tissue development. Molecular Cell 4 585-595. (doi:10.1016/S10972765(00)80209-9)

Baumann CG, Morris DG, Sreenan JM \& Leese HJ 2007 The quiet embryo hypothesis: molecular characteristics favoring viability. Molecular Reproduction and Development 74 1345-1353. (doi:10.1002/mrd.20604)

Baur JA, Pearson KJ, Price NL, Jamieson HA, Lerin C, Kalra A, Prabhu VV, Allard JS, Lopez-Lluch G, Lewis K et al. 2006 Resveratrol improves health and survival of mice on a high-calorie diet. Nature 444 337-342. (doi:10.1038/nature05354)

Benaitreau D, Dieudonne MN, Dos Santos E, Leneveu MC, Mazancourt P \& Pecquery R 2009 Antiproliferative effects of adiponectin on human trophoblastic cell lines JEG-3 and BeWo. Biology of Reproduction 80 1107-1114. (doi:10.1095/biolreprod.108.070573)

Brison DR \& Leese HJ 1991 Energy metabolism in late preimplantation rat embryos. Journal of Reproduction and Fertility 93 245-251. (doi:10.1530/jrf.0.0930245)

Brison DR \& Leese HJ 1994 Blastocoel cavity formation by preimplantation rat embryos in the presence of cyanide and other inhibitors of oxidative phosphorylation. Journal of Reproduction and Fertility 101 305-309. (doi:10.1530/jrf.0.1010305)

Burton GJ \& Jones CJ 2009 Syncytial knots, sprouts, apoptosis, and trophoblast deportation from the human placenta. Taiwanese Journal of Obstetrics \& Gynecology 48 28-37. (doi:10.1016/S10284559(09)60032-2)

Burton GJ, Yung HW, Cindrova-Davies T \& Charnock-Jones DS 2009 Placental endoplasmic reticulum stress and oxidative stress in the pathophysiology of unexplained intrauterine growth restriction and early onset preeclampsia. Placenta 30 (Suppl A) S43-S48. (doi:10.1016/ j.placenta.2008.11.003)

Burton GJ, Jauniaux E \& Charnock-Jones DS 2010 The influence of the intrauterine environment on human placental development. International Journal of Developmental Biology 54 303-312. (doi:10.1387/ ijdb.082764gb)

Caenepeel S, Charydczak G, Sudarsanam S, Hunter T \& Manning G 2004 The mouse kinome: discovery and comparative genomics of all mouse protein kinases. PNAS 101 11707-11712. (doi:10.1073/pnas. 0306880101)

Carter AM 2007 Animal models of human placentation - a review. Placenta 28 S41-S47. (doi:10.1016/j.placenta.2006.11.002)
Chai N, Patel Y, Jacobson K, McMahon J, McMahon A \& Rappolee DA 1998 FGF is an essential regulator of the fifth cell division in preimplantation mouse embryos. Developmental Biology 198 105-115. (doi:10.1016/ S0012-1606(98)80031-6)

Chakraborty C, Gleeson LM, McKinnon T \& Lala PK 2002 Regulation of human trophoblast migration and invasiveness. Canadian Journal of Physiology and Pharmacology 80 116-124. (doi:10.1139/y02-016)

Chen H, Detmer SA, Ewald AJ, Griffin EE, Fraser SE \& Chan DC 2003 Mitofusins Mfn1 and Mfn2 coordinately regulate mitochondrial fusion and are essential for embryonic development. Journal of Cell Biology 160 189-200. (doi:10.1083/jcb.200211046)

Cindrova-Davies T, Spasic-Boskovic O, Jauniaux E, Charnock-Jones DS \& Burton GJ 2007 Nuclear factor $-\kappa B$, p38, and stress-activated protein kinase mitogen-activated protein kinase signaling pathways regulate proinflammatory cytokines and apoptosis in human placental explants in response to oxidative stress: effects of antioxidant vitamins. American Journal of Pathology 170 1511-1520. (doi:10.2353/ajpath.2007. 061035)

Copp AJ 1995 Death before birth: clues from gene knockouts and mutations. Trends in Genetics 11 87-93. (doi:10.1016/S0168-9525 (00)89008-3)

Cowden Dahl KD, Fryer BH, Mack FA, Compernolle V, Maltepe E, Adelman DM, Carmeliet P \& Simon MC 2005 Hypoxia-inducible factors $1 \alpha$ and $2 \alpha$ regulate trophoblast differentiation. Molecular and Cellular Biology 25 10479-10491. (doi:10.1128/MCB.25.23.10479-10491. 2005)

Cowley S, Paterson H, Kemp P \& Marshall CJ 1994 Activation of MAP kinase kinase is necessary and sufficient for PC12 differentiation and for transformation of NIH 3T3 cells. Cell 77 841-852. (doi:10.1016/00928674(94)90133-3)

Cross JC, Anson-Cartwright L \& Scott IC 2002 Transcription factors underlying the development and endocrine functions of the placenta. Recent Progress in Hormone Research 57 221-234. (doi:10.1210/rp.57. 1.221)

Dimitriadis E, Nie G, Hannan NJ, Paiva P \& Salamonsen LA 2010 Local regulation of implantation at the human fetal-maternal interface. International Journal of Developmental Biology 54 313-322. (doi:10.1387/ijdb.082772ed)

Ferdous A, Morris J, Abedin MJ, Collins S, Richardson JA \& Hill JA 2011 Forkhead factor FoxO1 is essential for placental morphogenesis in the developing embryo. PNAS 108 16307-16312. (doi:10.1073/pnas. 1107341108)

Fischer B \& Bavister BD 1993 Oxygen tension in the oviduct and uterus of rhesus monkeys, hamsters and rabbits. Journal of Reproduction and Fertility 99 673-679. (doi:10.1530/jrf.0.0990673)

Geng Y, Yu Q, Sicinska E, Das M, Schneider JE, Bhattacharya S, Rideout WM, Bronson RT, Gardner H \& Sicinski P 2003 Cyclin E ablation in the mouse. Cell 114 431-443. (doi:10.1016/S0092-8674 (03)00645-7)

Giroux S, Tremblay M, Bernard D, Cardin-Girard JF, Aubry S, Larouche L, Rousseau S, Huot J, Landry J, Jeannotte L et al. 1999 Embryonic death of Mek1-deficient mice reveals a role for this kinase in angiogenesis in the labyrinthine region of the placenta. Current Biology 9 369-372. (doi:10.1016/S0960-9822(99)80164-X)

Hamatani T, Carter MG, Sharov AA \& Ko MS 2004 Dynamics of global gene expression changes during mouse preimplantation development. Developmental Cell 6 117-131. (doi:10.1016/S1534-5807(03)00373-3)

Hanahan D 1997 Signaling vascular morphogenesis and maintenance. Science 277 48-50. (doi:10.1126/science.277.5322.48)

Hirota Y, Acar N, Tranguch S, Burnum KE, Xie H, Kodama A, Osuga Y, Ustunel I, Friedman DB, Caprioli RM et al. 2010 Uterine FK506-binding protein 52 (FKBP52)-peroxiredoxin-6 (PRDX6) signaling protects pregnancy from overt oxidative stress. PNAS 107 15577-15582. (doi:10.1073/ pnas.1009324107)

Houghton FD, Thompson JG, Kennedy CJ \& Leese HJ 1996 Oxygen consumption and energy metabolism of the early mouse embryo. Molecular Reproduction and Development 44 476-485. (doi:10.1002/ (SICI)1098-2795(199608)44:4<476::AID-MRD7>3.0.CO;2-I)

Huppertz B 2008 Placental origins of preeclampsia: challenging the current hypothesis. Hypertension $\mathbf{5 1}$ 970-975. (doi:10.1161/HYPERTENSIONAHA.107.107607) 
Iwawaki T, Akai R, Yamanaka S \& Kohno K 2009 Function of IRE $1 \alpha$ in the placenta is essential for placental development and embryonic viability. PNAS 106 16657-16662. (doi:10.1073/pnas.0903775106)

Jauniaux E, Poston L \& Burton GJ 2006 Placental-related diseases of pregnancy: involvement of oxidative stress and implications in human evolution. Human Reproduction Update 12 747-755. (doi:10.1093/ humupd/dml016)

Jessmon P, Kilburn BA, Romero R, Leach RE \& Armant DR 2010 Functionspecific intracellular signaling pathways downstream of heparin-binding EGF-like growth factor utilized by human trophoblasts. Biology of Reproduction 82 921-929. (doi:10.1095/biolreprod.109.082305)

Kang SS, Woo SS, Im J, Yang JS, Yun CH, Ju HR, Son CG, Moon EY \& Han SH 2007 Human placenta promotes IL-8 expression through activation of JNK/SAPK and transcription factors NF-KB and AP-1 in PMA-differentiated THP-1 cells. International Immunopharmacology 7 1488-1495. (doi:10.1016/j.intimp.2007.07.011)

Katsanou V, Milatos S, Yiakouvaki A, Sgantzis N, Kotsoni A, Alexiou M, Harokopos V, Aidinis V, Hemberger M \& Kontoyiannis DL 2009 The RNA-binding protein Elavl1/HuR is essential for placental branching morphogenesis and embryonic development. Molecular and Cellular Biology 29 2762-2776. (doi:10.1128/MCB.01393-08)

Kawamura K, Sato N, Fukuda J, Kodama H, Kumagai J, Tanikawa H, Murata M \& Tanaka T 2003 The role of leptin during the development of mouse preimplantation embryos. Molecular and Cellular Endocrinology 202 185-189. (doi:10.1016/S0303-7207(03)00081-9)

Kedersha N \& Anderson P 2002 Stress granules: sites of mRNA triage that regulate mRNA stability and translatability. Biochemical Society Transactions 30 963-969. (doi:10.1042/BST0300963)

Knofler M 2010 Critical growth factors and signalling pathways controlling human trophoblast invasion. International Journal of Developmental Biology 54 269-280. (doi:10.1387/ijdb.082769mk)

Krasnow SM \& Steiner RA 2006 Physiological mechanisms integrating metabolism and reproduction. In Knobil and Neill's Physiology of Reproduction, third edition, ch 47, pp 2553-2626. Eds E Knobil E \& JD Neill. Amsterdam; Boston: Elsevier.

Kwong WY, Wild AE, Roberts P, Willis AC \& Fleming TP 2000 Maternal undernutrition during the preimplantation period of rat development causes blastocyst abnormalities and programming of postnatal hypertension. Development 127 4195-4202.

Lee N, Maurange C, Ringrose L \& Paro R 2005 Suppression of Polycomb group proteins by JNK signalling induces transdetermination in Drosophila imaginal discs. Nature 438 234-237. (doi:10.1038/ nature04120)

Leitao B, Jones MC, Fusi L, Higham J, Lee Y, Takano M, Goto T, Christian M, Lam EW \& Brosens JJ 2010 Silencing of the JNK pathway maintains progesterone receptor activity in decidualizing human endometrial stromal cells exposed to oxidative stress signals. FASEB Journal $\mathbf{2 4}$ 1541-1551. (doi:10.1096/fj.09-149153)

Liu L, Cash TP, Jones RG, Keith B, Thompson CB \& Simon MC 2006 Hypoxiainduced energy stress regulates mRNA translation and cell growth. Molecular Cell 21 521-531. (doi:10.1016/j.molcel.2006.01.010)

Liu J, Xu W, Sun T, Wang F, Puscheck E, Brigstock D, Wang QT, Davis R \& Rappolee DA 2009 Hyperosmolar stress induces global mRNA responses in placental trophoblast stem cells that emulate early post-implantation differentiation. Placenta 30 66-73. (doi:10.1016/j.placenta.2008.10.009)

Longtine MS, Chen B, Odibo AO, Zhong Y \& Nelson DM 2012 Caspasemediated apoptosis of trophoblasts in term human placental villi is restricted to cytotrophoblasts and absent from the multinucleated syncytiotrophoblast. Reproduction 143 107-121. (doi:10.1530/REP-11-0340)

Lucchi NW \& Moore JM 2007 LPS induces secretion of chemokines by human syncytiotrophoblast cells in a MAPK-dependent manner. Journal of Reproductive Immunology 73 20-27. (doi:10.1016/j.jri. 2006.05.005)

Ma Y, Zhu MJ, Uthlaut AB, Nijland MJ, Nathanielsz PW, Hess BW \& Ford SP 2011 Upregulation of growth signaling and nutrient transporters in cotyledons of early to mid-gestational nutrient restricted ewes. Placenta 32 255-263. (doi:10.1016/j.placenta.2011.01.007)

Maltepe E \& Simon MC 1998 Oxygen, genes, and development: an analysis of the role of hypoxic gene regulation during murine vascular development. Journal of Molecular Medicine 76 391-401. (doi:10.1007/ s001090050231)
Maltepe E, Schmidt JV, Baunoch D, Bradfield CA \& Simon MC 1997 Abnormal angiogenesis and responses to glucose and oxygen deprivation in mice lacking the protein ARNT. Nature 386 403-407. (doi:10. 1038/386403a0)

Maltepe E, Krampitz GW, Okazaki KM, Red-Horse K, Mak W, Simon MC \& Fisher SJ 2005 Hypoxia-inducible factor-dependent histone deacetylase activity determines stem cell fate in the placenta. Development $\mathbf{1 3 2}$ 3393-3403. (doi:10.1242/dev.01923)

Maltepe E, Bakardjiev AI \& Fisher SJ 2010 The placenta: transcriptional, epigenetic, and physiological integration during development. Journal of Clinical Investigation 120 1016-1025. (doi:10.1172/JCI41211)

Mazroui R, Di Marco S, Kaufman RJ \& Gallouzi IE 2007 Inhibition of the ubiquitin-proteasome system induces stress granule formation. Molecular Biology of the Cell 18 2603-2618. (doi:10.1091/mbc.E06-12-1079)

Mitchell JA \& Yochim JM 1968 Intrauterine oxygen tension during the estrous cycle in the rat: its relation to uterine respiration and vascular activity. Endocrinology 83 701-705. (doi:10.1210/endo-83-4-701)

Mitra K, Wunder C, Roysam B, Lin G \& Lippincott-Schwartz J 2009 A hyperfused mitochondrial state achieved at G1-S regulates cyclin E buildup and entry into S phase. PNAS 106 11960-11965. (doi:10.1073/ pnas.0904875106)

Mu XF, Jin XL, Farnham MM, Li Y \& O'Neill C 2011 DNA damage-sensing kinases mediate the mouse 2-cell embryo's response to genotoxic stress. Biology of Reproduction 85 524-535. (doi:10.1095/biolreprod.110. 089334)

Mudgett JS, Ding J, Guh-Siesel L, Chartrain NA, Yang L, Gopal S \& Shen MM 2000 Essential role for $p 38 \alpha$ mitogen-activated protein kinase in placental angiogenesis. PNAS 97 10454-10459. (doi:10.1073/pnas. 180316397)

Myatt L 2002 Role of placenta in preeclampsia. Endocrine 19 103-111. (doi:10.1385/ENDO:19:1:103)

Myatt L \& Miodovnik M 1999 Prediction of preeclampsia. Seminars in Perinatology 23 45-57. (doi:10.1016/S0146-0005(99)80059-7)

Myatt L \& Webster RP 2009 Vascular biology of preeclampsia. Journal of Thrombosis and Haemostasis 7 375-384. (doi:10.1111/j.1538-7836. 2008.03259.x)

Oikawa D \& Kimata Y 2011 Experimental approaches for elucidation of stress-sensing mechanisms of the IRE1 family proteins. Methods in Enzymology 490 195-216. (doi:10.1016/B978-0-12-385114-7.00012-X)

Owusu-Ansah E \& Banerjee U 2009 Reactive oxygen species prime Drosophila haematopoietic progenitors for differentiation. Nature $\mathbf{4 6 1}$ 537-541. (doi:10.1038/nature08313)

Parisi T, Beck AR, Rougier N, McNeil T, Lucian L, Werb Z \& Amati B 2003 Cyclins E1 and E2 are required for endoreplication in placental trophoblast giant cells. EMBO Journal 22 4794-4803. (doi:10.1093/ emboj/cdg482)

Pringle KG, Kind KL, Sferruzzi-Perri AN, Thompson JG \& Roberts CT 2010 Beyond oxygen: complex regulation and activity of hypoxia inducible factors in pregnancy. Human Reproduction Update 16 415-431. (doi:10. 1093/humupd/dmp046)

Rappolee DA 1999 It's not just baby's babble/Babel: recent progress in understanding the language of early mammalian development: a minireview. Molecular Reproduction and Development 52 234-240. (doi:10.1002/(SICl)1098-2795(199902)52:2 <234::AID-MRD15>3.0. $\mathrm{CO} ; 2-\mathrm{H})$

Rappolee DA 2007 Impact of transient stress and stress enzymes on development. Developmental Biology 304 1-8. (doi:10.1016/j.ydbio. 2006.12.032)

Rappolee DA, Awonuga AO, Puscheck EE, Zhou S \& Xie Y 2010 Benzopyrene and experimental stressors cause compensatory differentiation in placental trophoblast stem cells. Systems Biology in Reproductive Medicine 56 168-183. (doi:10.3109/19396360903431638)

Rappolee DA, Xie YF, Zhou SC, Huttemann M, Lee IS \& Puscheck EE 2011 a Hypoxia induces maximal preparation for, but incomplete differentiation of stem cells that is associated with decreased mitochondrial function and increased expression of two potency factors. Fertility and Sterility 96 S169. (doi:10.1016/j.fertnstert.2011.07.661)

Rappolee DA, Xie YF, Zhou SC, Slater J \& Puscheck EE $2011 b$ Cellular and toxicological stress cause adaptive "prioritized" and "compensatory" differentiation of embryonic and placental stem cells of the implanting blastocyst. Fertility and Sterility 96 S171. (doi:10.1016/j.fertnstert.2011. 07.666) 
Rappolee DA, Xie Y, Slater JA, Zhou S \& Puscheck EE 2012 Toxic stress prioritizes and imbalances stem cell differentiation: implications for new biomarkers and in vitro toxicology tests. Systems Biology in Reproductive Medicine 58 33-40. (doi:10.3109/19396368.2011.647381)

Red-Horse K, Drake PM \& Fisher SJ 2004a Human pregnancy: the role of chemokine networks at the fetal-maternal interface. Expert Reviews in Molecular Medicine 2004 1-14. (doi:http://dx.doi.org/10.1017/S146 2399404007720)

Red-Horse K, Zhou Y, Genbacev O, Prakobphol A, Foulk R, McMaster M \& Fisher SJ 2004b Trophoblast differentiation during embryo implantation and formation of the maternal-fetal interface. Journal of Clinical Investigation 114 744-754. (doi:10.1172/JCI22991)

Robb L, Li R, Hartley L, Nandurkar HH, Koentgen F \& Begley CG 1998 Infertility in female mice lacking the receptor for interleukin 11 is due to a defective uterine response to implantation. Nature Medicine 4 303-308. (doi:10.1038/nm0398-303)

Roberts JM \& Hubel CA 2009 The two stage model of preeclampsia: variations on the theme. Placenta 30 S32-S37. (doi:10.1016/j.placenta. 2008.11.009)

Roberts RM, Ezashi T \& Das P 2004 Trophoblast gene expression: transcription factors in the specification of early trophoblast. Reproductive Biology and Endocrinology 2 47. (doi:10.1186/1477-7827-2-47)

Rosario GX, Konno T \& Soares MJ 2008 Maternal hypoxia activates endovascular trophoblast cell invasion. Developmental Biology 314 362-375. (doi:10.1016/j.ydbio.2007.12.007)

Rossant J \& Cross JC 2001 Placental development: lessons from mouse mutants. Nature Reviews. Genetics 2 538-548. (doi:10.1038/35080570)

Salamonsen LA, Hannan NJ \& Dimitriadis E 2007 Cytokines and chemokines during human embryo implantation: roles in implantation and early placentation. Seminars in Reproductive Medicine 25 437-444. (doi:10.1055/s-2007-991041)

Schiessl B 2007 Inflammatory response in preeclampsia. Molecular Aspects of Medicine 28 210-219. (doi:10.1016/j.mam.2007.04.004)

Schmidt D, Textor B, Pein OT, Licht AH, Andrecht S, Sator-Schmitt M, Fusenig NE, Angel P \& Schorpp-Kistner M 2007 Critical role for NF-KBinduced JunB in VEGF regulation and tumor angiogenesis. EMBO Journal 26 710-719. (doi:10.1038/sj.emboj.7601539)

Schoenwolf GC \& Larsen WJ 2009 In Larsen's Human Embryology. 4th edition. Philadelphia, PA, USA: Churchill Livingstone/Elsevier.

Schorpp-Kistner M, Wang ZQ, Angel P \& Wagner EF 1999 JunB is essential for mammalian placentation. EMBO Journal 18 934-948. (doi:10.1093/ emboj/18.4.934)

Scifres CM \& Nelson DM 2009 Intrauterine growth restriction, human placental development and trophoblast cell death. Journal of Physiology 587 3453-3458. (doi:10.1113/jphysiol.2009.173252)

Sebastiano V, Dalvai M, Gentile L, Schubart K, Sutter J, Wu GM, Tapia N, Esch D, Ju JY, Hubner K et al. 2010 Oct1 regulates trophoblast development during early mouse embryogenesis. Development 137 3551-3560. (doi:10.1242/dev.047027)

Seeber BE 2012 What serial hCG can tell you, and cannot tell you, about an early pregnancy. Fertility and Sterility 98 1074-1077. (doi:10.1016/ j.fertnstert.2012.09.014)

Shaulian E \& Karin M 2002 AP-1 as a regulator of cell life and death. Nature Cell Biology 4 E131-E136. (doi:10.1038/ncb0502-e131)

Simmons DG \& Cross JC 2005 Determinants of trophoblast lineage and cell subtype specification in the mouse placenta. Developmental Biology 284 12-24. (doi:10.1016/j.ydbio.2005.05.010)

Simmons DG, Fortier AL \& Cross JC 2007 Diverse subtypes and developmental origins of trophoblast giant cells in the mouse placenta. Developmental Biology 304 567-578. (doi:10.1016/j.ydbio.2007. 01.009)

Soares MJ, Konno T \& Alam SM 2007 The prolactin family: effectors of pregnancy-dependent adaptations. Trends in Endocrinology and Metabolism 18 114-121. (doi:10.1016/j.tem.2007.02.005)

Stumpo DJ, Byrd NA, Phillips RS, Ghosh S, Maronpot RR, Castranio T, Meyers EN, Mishina Y \& Blackshear PJ 2004 Chorioallantoic fusion defects and embryonic lethality resulting from disruption of Zfp36L1, a gene encoding a $\mathrm{CCCH}$ tandem zinc finger protein of the Tristetraprolin family. Molecular and Cellular Biology 24 6445-6455. (doi:10.1128/ MCB.24.14.6445-6455.2004)
Tal J, Kaplan M, Sharf M \& Barnea ER 1991 Stress-related hormones affect human chorionic gonadotrophin secretion from the early human placenta in vitro. Human Reproduction 6 766-769.

Tanaka S, Kunath T, Hadjantonakis AK, Nagy A \& Rossant J 1998 Promotion of trophoblast stem cell proliferation by FGF4. Science 282 2072-2075. (doi:10.1126/science.282.5396.2072)

Tong S, Wallace EM \& Rombauts L 2006 Association between low day 16 hCG and miscarriage after proven cardiac activity. Obstetrics and Gynecology 107 300-304. (doi:10.1097/01.AOG.0000196505.09016.f3)

Voss AK, Thomas T \& Gruss P 2000 Mice lacking HSP90ß fail to develop a placental labyrinth. Development 127 1-11.

Wang QT, Piotrowska K, Ciemerych MA, Milenkovic L, Scott MP, Davis RW \& Zernicka-Goetz M 2004 A genome-wide study of gene activity reveals developmental signaling pathways in the preimplantation mouse embryo. Developmental Cell 6 133-144. (doi:10.1016/S1534-5807(03) 00404-0)

Wang Y, Puscheck EE, Lewis JJ, Trostinskaia AB, Wang F \& Rappolee DA 2005 Increases in phosphorylation of SAPK/JNK and p38MAPK correlate negatively with mouse embryo development after culture in different media. Fertility and Sterility 83 (Suppl 1) 1144-1154. (doi:10.1016/ j.fertnstert.2004.08.038)

Watson ED \& Cross JC 2005 Development of structures and transport functions in the mouse placenta. Physiology 20 180-193. (doi:10.1152/ physiol.00001.2005)

Wiemers DO, Shao LJ, Ain R, Dai G \& Soares MJ 2003 The mouse prolactin gene family locus. Endocrinology 144 313-325. (doi:10.1210/en.2002220724)

Xie Y, Puscheck EE \& Rappolee DA 2006 Effects of SAPK/JNK inhibitors on preimplantation mouse embryo development are influenced greatly by the amount of stress induced by the media. Molecular Human Reproduction 12 217-224. (doi:10.1093/molehr/gal021)

Xie Y, Zhong W, Wang Y, Trostinskaia A, Wang F, Puscheck EE \& Rappolee DA 2007 Using hyperosmolar stress to measure biologic and stress-activated protein kinase responses in preimplantation embryos. Molecular Human Reproduction 13 473-481. (doi:10.1093/molehr/ gam027)

Xie Y, Liu J, Proteasa S, Proteasa G, Zhong W, Wang Y, Wang F, Puscheck EE \& Rappolee DA 2008 Transient stress and stress enzyme responses have practical impacts on parameters of embryo development, from IVF to directed differentiation of stem cells. Molecular Reproduction and Development 75 689-697. (doi:10.1002/mrd.20787)

Xie Y, Abdallah ME, Awonuga AO, Slater JA, Puscheck EE \& Rappolee DA 2010 Benzo(a)pyrene causes PRKAA1/2-dependent ID2 loss in trophoblast stem cells. Molecular Reproduction and Development 77 533-539. (doi:10.1002/mrd.21178)

Xie Y, Awonuga AO, Zhou S, Puscheck EE \& Rappolee DA 2011 Interpreting the stress response of early mammalian embryos and their stem cells. International Review of Cell and Molecular Biology 287 43-95. (doi:10.1016/B978-0-12-386043-9.00002-5)

Xie Y, Awonuga A, Liu J, Rings E, Puscheck E \& Rappolee D 2013 Stress induces AMPK-dependent loss of potency factors Cdx2 and Id2 in early embryos and stem cells. Stem Cells and Development. (doi:10.1089/scd.2012.0352)

Xu P \& Davis RJ 2010 c-Jun NH2-terminal kinase is required for lineagespecific differentiation but not stem cell self-renewal. Molecular and Cellular Biology 30 1329-1340. (doi:10.1128/MCB.00795-09)

Yang P, Zhao Z \& Reece EA 2007 Involvement of c-Jun N-terminal kinases activation in diabetic embryopathy. Biochemical and Biophysical Research Communications 357 749-754. (doi:10.1016/j.bbrc.2007. 04.023)

Yang P, Zhao Z \& Reece EA 2008a Activation of oxidative stress signaling that is implicated in apoptosis with a mouse model of diabetic embryopathy. American Journal of Obstetrics and Gynecology 198 130.e1-130.e7. (doi:10.1016/j.ajog.2007.06.070)

Yang P, Zhao Z \& Reece EA $2008 b$ Blockade of c-Jun N-terminal kinase activation abrogates hyperglycemia-induced yolk sac vasculopathy in vitro. American Journal of Obstetrics and Gynecology 198 321.e1-321.e7. (doi:10.1016/j.ajog.2007.09.010)

Zhong W, Sun T, Wang QT, Wang Y, Xie Y, Johnson A, Leach R, Puscheck EE \& Rappolee DA 2004 SAPK $\gamma /$ JNK1 and SAPK $\alpha /$ JNK2 mRNA transcripts 
are expressed in early gestation human placenta and mouse eggs, preimplantation embryos, and trophoblast stem cells. Fertility and Sterility 82 (Suppl 3) 1140-1148. (doi:10.1016/j.fertnstert.2004.06.014)

Zhong W, Xie Y, Wang Y, Lewis J, Trostinskaia A, Wang F, Puscheck EE \& Rappolee DA 2007 Use of hyperosmolar stress to measure stressactivated protein kinase activation and function in human HTR cells and mouse trophoblast stem cells. Reproductive Sciences 14 534-547. (doi:10.1177/1933719107307182)

Zhong W, Xie Y, Abdallah M, Awonuga AO, Slater JA, Sipahi L, Puscheck EE \& Rappolee DA 2010 Cellular stress causes reversible, PRKAA1/2-, and proteasome-dependent ID2 protein loss in trophoblast stem cells. Reproduction 140 921-930. (doi:10.1530/REP-10-0268)

Zhou S, Xie Y, Puscheck EE \& Rappolee DA 2011 Oxygen levels that optimize TSC culture are identified by maximizing growth rates and minimizing stress. Placenta 32 475-481. (doi:10.1016/j.placenta.2011. 03.013)
Zhu MJ, Du M, Nijland MJ, Nathanielsz PW, Hess BW, Moss GE \& Ford SP 2009 Down-regulation of growth signaling pathways linked to a reduced cotyledonary vascularity in placentomes of over-nourished, obese pregnant ewes. Placenta 30 405-410. (doi:10.1016/j.placenta. 2009.02.001)

Zhu MJ, Du M, Nathanielsz PW \& Ford SP 2010 Maternal obesity up-regulates inflammatory signaling pathways and enhances cytokine expression in the mid-gestation sheep placenta. Placenta 31 387-391. (doi:10.1016/j.placenta.2010.02.002)

Received 5 July 2012

First decision 10 August 2012

Revised manuscript received 17 February 2013

Accepted 5 March 2013 